\title{
MiRNA Dysregulation in Childhood Hematological Cancer
}

\author{
Jaqueline Carvalho de Oliveira ${ }^{1}$, Gabriela Molinari Roberto ${ }^{2}$, Mirella Baroni ${ }^{2}$, \\ Karina Bezerra Salomão ${ }^{2}{ }^{(1)}$, Julia Alejandra Pezuk ${ }^{3}$ and María Sol Brassesco ${ }^{4, *(1)}$ \\ 1 Department Genetics, Federal University of Paraná, 80060-000 Paraná, Brazil; jaqbiomed@yahoo.com.br \\ 2 Department of Pediatrics, Ribeirão Preto School of Medicine, University of São Paulo, \\ 14049-900 Ribeirão Preto, Brazil; gabi_cdl@hotmail.com (G.M.R.); \\ mirella_baroni@yahoo.com.br (M.B.); karina_slm@hotmail.com (K.B.S.) \\ 3 Programa de Pós-graduação em Farmácia, Anhanguera University of São Paulo, UNIAN/SP, \\ 05145-200 São Paulo, Brazil; julia.pezuk@hotmail.com \\ 4 Departamento de Biologia, Faculty of Philosophy, Sciences and Letters at Ribeirão Preto, \\ University of São Paulo, 14040-901 Ribeirão Preto, Brazil \\ * Correspondence: solbrassesco@usp.br; Tel.: +55-16-3315-9144; Fax: +55-16-3315-4886
}

Received: 20 July 2018; Accepted: 8 September 2018; Published: 10 September 2018

check for updates

\begin{abstract}
For decades, cancer biology focused largely on the protein-encoding genes that have clear roles in tumor development or progression: cell-cycle control, apoptotic evasion, genome instability, drug resistance, or signaling pathways that stimulate growth, angiogenesis, or metastasis. MicroRNAs (miRNAs), however, represent one of the more abundant classes of cell modulators in multicellular organisms and largely contribute to regulating gene expression. Many of the $\sim 2500$ miRNAs discovered to date in humans regulate vital biological processes, and their aberrant expression results in pathological and malignant outcomes. In this review, we highlight what has been learned about the roles of miRNAs in some of the most common human pediatric leukemias and lymphomas, along with their value as diagnostic/prognostic factors.
\end{abstract}

Keywords: miRNA; cancer; children; leukemia; lymphoma; review

\section{Introduction}

Following the first microRNA (miRNA) discovery in 1993 [1], a constantly increasing number of miRNAs have been described and investigated. In 2002, the first miRNA dysregulation associated with human disease revealed deletion of miR-15 and miR-16 as a frequent event in chronic lymphocytic leukemia patients [2]. A year later, another couple of miRNAS, miR-143 and miR-145, were described as downregulated in colon adenocarcinoma [3].

In 2004, Calin and colleagues mapped 186 miRNAs and found that over $50 \%$ of miRNA genes are located at cancer-associated genomic regions or in fragile sites, and that those located in deleted regions are generally downregulated in cancer samples [4]. In the same year, let-7 was associated with shortened postoperative survival in lung cancer [5] and it was identified as a specific miRNA profile in B cell chronic lymphocytic leukemia [6].

Thenceforth, many miRNAs have been identified to have an essential role in human carcinogenesis and progression. Several reports have shown that miRNAs are central in cancer pathways by acting as "oncomiRs" or "tumor-suppressive miRNAs" and are often related to apoptosis, cell proliferation, angiogenesis, metastasis, and drug resistance $[7,8]$. Furthermore, miRNA regulation is dependent on the expression of its multiple mRNA targets, which are not always constitutively expressed; consequently, a unique miRNA may have different effects under diverse conditions [9]. 
The biological behavior of pediatric tumors is heterogeneous with several aspects distinguishing them from their adult counterparts, including their location, cellular environment, cell of origin, and genetic mutations. From treatment perspectives, they are also heterogeneous, ranging from generally curable low-grade tumors to highly aggressive forms that are usually fatal. Consequently, the identification of molecular markers that can effectively predict prognosis, and might contribute to the development of new therapeutic approaches, is still needed.

Like in adults, dysregulation of miRNAs is a hallmark in childhood cancer. Herein, we will compile current information about the role of miRNAs in the biology of leading hematological cancers in a pediatric setting.

\section{Leukemias}

Leukemia, a cancer of the bone marrow (BM) that hampers normal hematopoiesis, is the most common childhood malignancy, accounting for about $30 \%$ of all pediatric cancer. The two major subtypes seen in children are acute lymphoblastic leukemia (ALL), and acute myeloid leukemia (AML) $[10,11]$, though a small fraction may present chronic myeloid leukemia (CML) and juvenile myelomonocytic leukemia (JMML) [12,13].

\subsection{Acute Lymphoblastic Leukemia}

ALL represents $80 \%$ of all leukemia types in children [10] and in recent decades clinicians have seen a significant improvement in event-free survival (EFS) rates, currently exceeding $80 \%$ in developed nations [14]. This advancement was notably facilitated by multiagent chemotherapy regimens and risk-adapted therapy, where the study of laboratory-based outcome variables consents the allocation of treatment $[14,15]$.

In 2007, Mi and colleagues [16] showed that miRNA signatures could accurately discriminate ALL from AML. This study, although samples from adult and pediatric patients were analyzed indiscriminately, was the first suggestion of miRNAs' involvement in childhood leukemia. Thereafter, many research groups also utilized miRNA-expression analyses and proved this strategy to be useful in the refinement of ALL classification schemes. Nowadays, disruption of miRNA expression and function in ALL is the most broadly studied and well-characterized among pediatric leukemias (Figure 1).

Differentially expressed miRNAs in childhood ALL (cALL) were firstly described in 2009 [17]. Examining 40 newly diagnosed pre-B ALL samples, miR-222, miR-339, and miR-142-3p were found overexpressed, along with the downregulation of miR-451 and miR-373 when compared to normal cells [17]. Additionally, a subsequent report [18] examined miRNA profiles in pediatric ALL samples in comparison to normal CD34 ${ }^{+}$cells, and gave evidence of the upregulation of miR-128a, miR-142, miR-150, miR-181, miR-30e-5p, miR-193, miR-34b, miR-365, miR-582, and miR-708, and the downregulation of miR-100, miR-125b, miR-99a, miR-196b, and miR-let-7e. Later on, several studies reported dysregulated miRNA expression in pediatric ALL samples compared to normal cells. For example, a number of publications described increased expression of miR-21, miR-34, miR-128, miR-142, miR-146a, miR-181b, miR-195, and miR-708 [19-23], and decreased levels of miR-18, miR-181a, miR-99a, miR-100, miR-145, let-7, and miR-196b in ALL cells [19,21,24,25].

The biological heterogeneity and distinct-lineage origins of ALL are well-established [26]. Such heterogeneity is also reflected with respect to miRNA expression profiles, for example, miR-18a is lower in childhood ALL when compared to the adult counterparts [24]. Among the dysregulation of miRNAs evinced in multiples studies, specific miRNA profiles have been described for specific ALL subtypes [18]. The same group [27] later identified unique miRNA expression patterns for each pediatric ALL subtype and measured the expression levels of 397 miRNAs in samples from 81 patients. The authors were able to differentiate many of the major subtypes of ALL, such as T-cell, MLL-rearranged, ETV6/RUNX1-positive, E2A/PBX1-positive, and hyperdiploid. However, conclusive evidence for discriminative miRNA expression was not found in $B C R / A B L$ positive and "B-other groups". 
Moreover, the downregulation of miR-let-7b ( 70-fold) in MLL-rearranged ALL; miR-100 in ETV6/RUNX1-positive; miR-17-3p, miR-17-5p, miR-29c-3p, miR-92a-3p, miR-214-3p, miR-214-5p, miR-708 in T-ALL; and miR-31, miR-24, miR-708, and miR-128 were associated with PAX5-deleted ALL $[18,20,28,29]$. Contrariwise, higher expression of miR-125b, miR-196, miR-223, and miR-708 were found in patients with ETV6/RUNX1 translocation, and miR-24 and miR-542 were associated with PAR1 deletion, ALL [27,29,30] increased miR-181b and miR-128a in MLL-rearranged [20,27,31], higher miR-100 and miR-21 in B-ALL, and higher miR-196b in T-ALL [19,32-34]. Moreover, a difference on miRNA expression was found when infant and childhood T-ALL were compared [35].

The clinical importance of miRNA profiling was also verified by the description of an association with treatment resistance and EFS. Specific miRNA profiles were described for several commonly used drugs (Figure 2). A study published in 2015 by Hamzeh et al. showed that miRNA-related dysregulated pathways were associated to resistance to asparaginase (L_ASP), daunorubicin (DAUNO), prednisolone (PREDS), and vincristine (VIN) [36]. Several miRNAs have been attributed an association with leukemia treatment resistance, such as miR-34 [37,38], miR-128b, and miR-223 [39]. Zhang et al. [23] described an miRNA signature (miR-18a, miR-532, miR-218, miR-625, miR-193a, miR-638, miR-550, and miR-633) that was able to predict prednisone (PRED) response in childhood ALL patients. Later, in a separate study involving cALL samples, it was shown that the expression profiles of the same group of miRNAs could similarly be used to predict early response to this glucocorticoid [40]. Furthermore, miR-124 was upregulated in prednisone and glucocorticoid resistance [41]. Alternatively, it was shown that prednisolone significantly increased miR-16-1 and miR-15a expression [42]. Additionally, it has been demonstrated that the restoration of miR-128b and miR-221 co-operatively sensitizes MLL/AF4(+) ALL cell lines to glucocorticoids [43], while exogenous expression of miR-335 in ALL cells renders cells to PREDS-mediated apoptosis [44].

Comparatively, in an attempt to elucidate miRNA signatures that indicate sensitivity to other chemotherapeutics used in ALL treatment, 397 miRNA were verified by Schotte and colleagues [27]. From those, 17 were related to resistance to one or more drugs. Among them, miR-99a, miR-100, miR-125b, and miR-126 were associated with VIN and DAUNO resistance, while miR-625 was associated with VIN and PREDS resistance. The expression of miR-125b, together with miR-99a and/or miR-100 overexpression, is also linked to vincristine resistance $[45,46]$, while the overexpression of miR-652-3p increases sensitivity to vincristine and cytarabin (CYT) [47]. Recently, downregulation miR-326 was associated with multidrug resistance [48].

Furthermore, miR-3117-3p polymorphism has been associated with vincristine-induced neurotoxicity [49]. Moreover, miR-5189, miR-595, miR-6083, and some polymorphisms related to miRNA can also be linked to methotrexate (MTX) response, and miR-1206 can be used to predict MTX toxicity [50-52].

On the other hand, the association of distinct miRNA expression patterns in relation to risk stratification in childhood ALL has been scrutinized in the literature. A report by Zhang et al. [23] alluded to the association of miRNA expression with prognostic parameters such Central Nervous system (CNS) relapse, specific risk category, and disease recurrence. More than $20 \%$ of patients with CNS relapse showed a threefold increase of miR-7, miR-198, and miR-633, and a decrease of miR-126, miR-345, miR-222, and miR-551a at a one-year follow-up. Some of these findings were later confirmed in a report by $\mathrm{Xu}$ and colleagues [40].

The expression of some miRNAs can be used to monitor disease progression, such as with miR-128, miR-146a, miR-155, miR-181a, and miR-195 [21]. In addition, miR-210 has been proposed as a good prognostic factor and a useful predictor of drug sensitivity [53]. Moreover, a systematic investigation by Schotte et al. [27] verified a correlation with the probability of disease-free survival (DFS) and expression levels of 31 distinct miRNAs. Among those, 14 miRNAs were considered independent prognostic factors that allowed the distinction of a group of patients with favorable expression profiles and a five-year DFS of $89.4 \pm 7 \%$ from those with less favorable miRNA profiles, with a five-year DFS rate of $60.8 \pm 12 \%$. 
In parallel, Han et al. [54], using panel of matched samples (diagnosis/remission and diagnosis/relapse), described the altered expression of miR-223, miR-23a, let-7g, miR-181, miR-708, and miR-130b in relapsed samples, and miR-27a, miR-223, miR-23a, miR-181, and miR-128b in samples taken at remission. MiRNAs expression associated with shorter EFS or other clinical markers in cALL were also described $[39,53,55-58]$. An association of miR-708, miR-223, and miR-27a with relapse-free survival (RFS) was also demonstrated, as well as a prediction for relapse in patients with altered expression of miR-210 and for miR-143/miR-182 [59,60]. Moreover, the low expression of miR-151-5p and miR-451, high expression of miR-1290, or a combination of all three predicted inferior RFS [61].

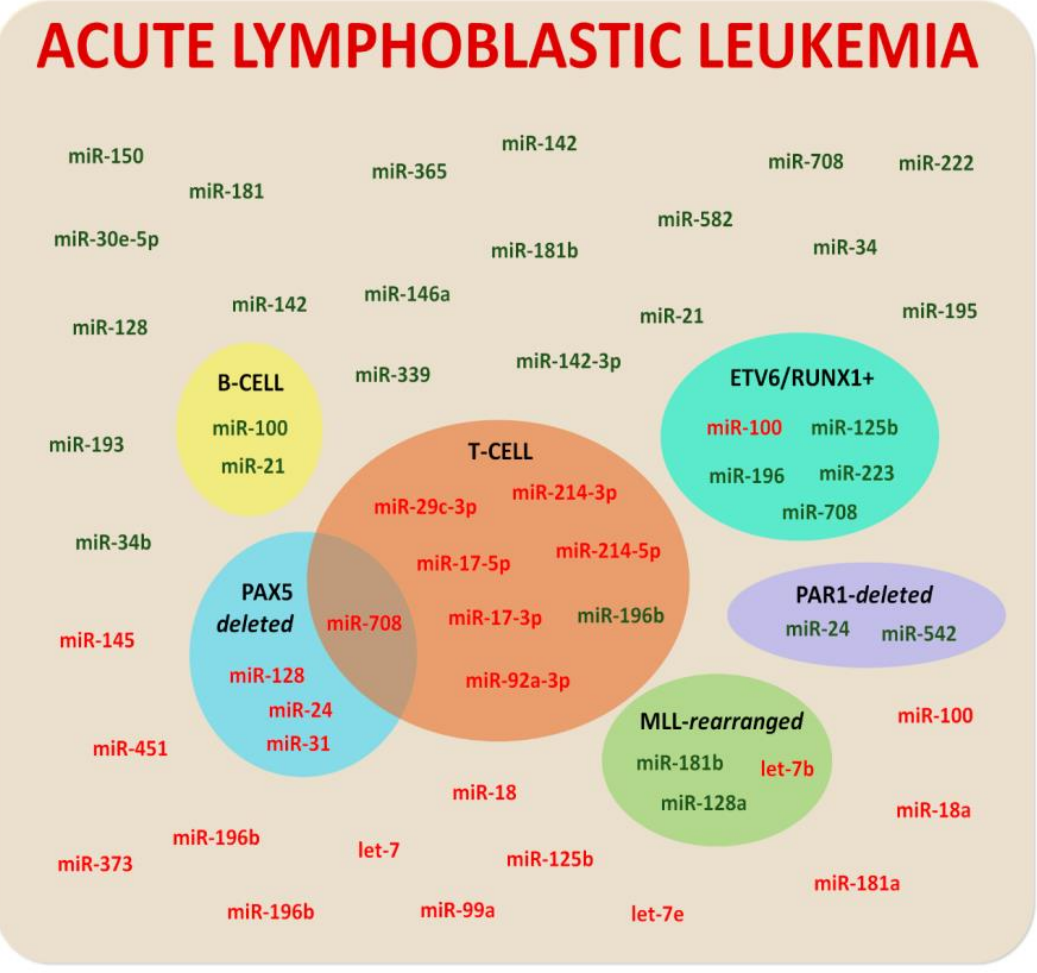

Figure 1. Dysregulated microRNAs (miRNAs) in childhood acute lymphoblastic leukemia. Hyperexpressed and hypoexpressed miRNAs in acute lymphoblastic leukemia within cellular (B-cell or T-cell) or molecular (ETV6/RUNX1+, PAX5-deleted, MLL-rearranged, or PAR1-deleted) subgroups are denoted in green and red, respectively.

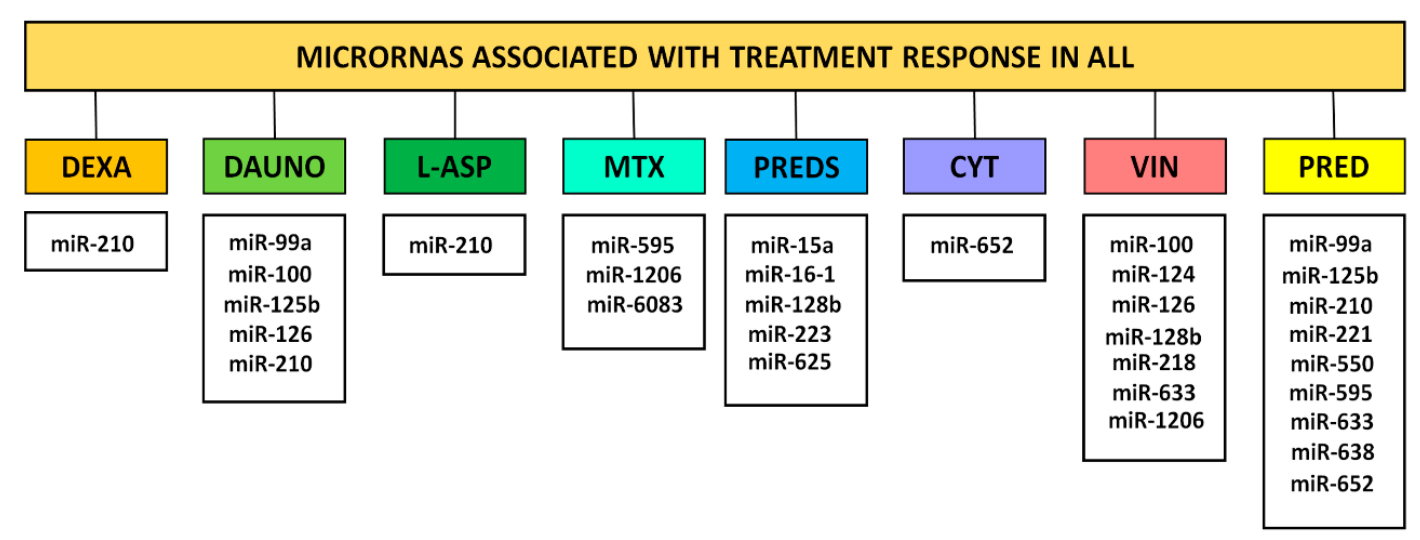

Figure 2. Dysregulated miRNAS that are associated with treatment response. Several miRNAs have been attributed an association with differential responses to dexamethasone (DEXA), daunorrubicin (DAUNO), L-asparaginase (L-ASP), methotrexate (MTX), prednisolone (PREDS), cytarabin (CYT), vincristine (VIN), or prednisone (PRED). 


\subsection{Acute Myeloid Leukemia}

Acute myeloid leukemia (AML) is the second most common type of pediatric leukemia, representing $17 \%$ of all hematological cancer in children [10] and five-year survival estimates of approximately $65 \%$ in developed countries [62]. MiRNA dysregulation has also been described in this pathology, though to a much lower extent when compared to ALL (Figure 3).

The first analysis of miRNA signatures in childhood AML (cAML) was also described by Mi and colleagues [16]. Nonetheless, adult and pediatric patients were analyzed indiscriminately and, among the 93 AML cases analyzed, only 17 were under 18 years old (nine patients under 12 years-old).

In 2009, samples from patients diagnosed with AML showed low levels of miR-34b, while in vitro exogenous expression of this miRNA caused cell-cycle abnormalities, reduced anchorage-independent growth, and altered CREB (cAMP response element-binding protein) target gene expression, suggesting suppressor potential [63]. Furthermore, in 2013, the same group demonstrated the hypermethylation of miR-34b promoter in AML [63].

Hypermethylation of the miR-663 promoter was also observed in another pediatric AML cohort and, consequently, a significantly lower expression of this miRNA was observed compared to normal bone-marrow control samples [64].

Several research groups have widely explored the study of individual miRNAs in AML. Emmrich et al. [65] observed that miR-582 and miR-9 are downregulated in t(8;21) AML; miR-500a and miR-192/194 are downregulated in AML with inv (16); and miR-181a, miR-1331, and miR-126 are downregulated while miR-187 is increased in MLL-rearranged AML. In 2017, Obulkasim et al. [66] published a signature prolife of 47 miRNAs to distinguished different AML cytogenetic subtypes. Moreover, miR-155 was proposed as a potential diagnostic biomarker for all AML, whereas miR-196b is specific for subgroups M4-M5 [67,68]. Another study stated that high miR-155 expression is also an adverse prognostic factor in pediatric NK-AML and is associated with worse EFS and overall survival (OS) [69].

In addition, miR-193b-3p was described as downregulated and proposed as an independent indicator for poor prognosis in pediatric AML, independent of patient age or genetics [70]. MiR-146b was described as an independent poor prognostic factor, while high expression of miR-181c and miR-4786 appeared to be favorable factors [71]. High expression of miR-196b in diagnostic marrow samples of pediatric AML was also associated with an unfavorable outcome [72].

Upregulation of miR-100 and miR-375 was also correlated with poor RFS OS [73], and downregulation of miR-29a was associated with advanced clinical features and poor prognosis of pediatric patients [74]. More, recently, an miRNA-based predictor of poststandard induction chemotherapy outcome in cAML was created to identify EFS in children with AML, and it offers the potential for improved patient stratification and management [75].

On the other hand, Danen-van Oorschot and colleagues [76] showed high levels of miR-196a and -b expression in pediatric patients carrying MLL fissions, NPM1 mutations, or FLT3/ITD. In contrast, CEBPA-mutated cases presented low expression of miR-196a and - $b$. Alternatively, high expression of miR-155 was also observed in FLT3/ITD and NPM1-mutated cases, while downregulation of miR-29a was mostly detected in MLL-rearranged samples [76]. Moreover, the miR-106b 25 cluster has shown to be upregulated in relapse pediatric AML with MLL rearrangements [77].

Another comprehensive overview of miRNA expression showed that samples with core-binding factor AML and promyelocytic leukemia differed from each other and could be distinguished from $M L L$-rearranged AML subtypes by differentially expressed miRNAs that included miR-126, -146a, $-181 \mathrm{a} / \mathrm{b},-100$, and miR-125b [78].

MiR-99a was also found highly expressed in pediatric-onset AML, while significantly underexpressed during complete remission. Additionally, in vitro studies suggested a potential oncogenic role [79]. Moreover, forced expression of miR-9 reduced leukemic growth and induced monocytes differentiation of $t(8 ; 21)$ AML cell lines in vitro and in vivo, being characterized as a tumor-suppressor miRNA that acts in a strict cell context-dependent manner [65]. 
In parallel, many miRNAs have been related to AML by regulating cell proliferation, including downregulation of miR-122 as an aggressive progression marker [80], and miR-181a as a regulator of G1/S transition [81]. Others, like miR-126 and miR-182, were highly expressed in AML cell lines and inhibition of miR-126 significantly induced cell death through apoptosis $[82,83]$

\subsection{Chronic Myeloid Leukemia}

Chronic myeloid leukemia (CML) is a rare childhood hematological malignancy representing around $3 \%$ of all leukemias, with an annual incidence of one per million children and young people aged $<15$ years [84].

The characteristic reciprocal translocation $\mathrm{t}(9 ; 22)(\mathrm{q} 34 ; \mathrm{q} 11)$ that leads to the formation of $B C R / A B L$ chimeric oncoprotein is present in 90-95\% of childhood CML [85]. In the era of therapy with specific tyrosine kinase inhibitors, the two-year survival among children with CML is $81-89 \%$; nonetheless, age-group analysis evidenced that risk of death was three times higher for children younger than five years versus those aged 10-14 years [86].

Independent of age, many miRNAs have been described as active regulators of $A B L 1$ and $B C R / A B L$. For example, it was demonstrated that $A B L 1$ is a direct target of miR-203. This miRNA is silenced in CML and its restoration reduces $A B L 1$ and $B C R / A B L 1$ expression, decreasing cell growth. Additionally, one of the molecular mechanisms of imatinib is the demethylation of miR-203 in $B C R / A B L$-positive leukemia cells $[87,88]$. Nevertheless, the specific role of miRNAs in pediatric CML has been little explored. In 2013, miR-99a expression levels were evaluated in eight CML patients (including four samples before therapy and four samples with complete remission) and 12 pediatric controls. Although with a small number of patients, miR-99a expression was significantly increased in samples collected at diagnosis and decreased in samples after treatment [79].

A more recent study, aiming to evaluate profibrotic changes in childhood CML, analyzed 16 pediatric and 16 adult CML samples with and without fibrosis (each $n=8$ ), as well as 18 non-neoplastic controls. Fiber accumulation in BM represents an adverse prognostic factor in adult CML, but, in children, this event is unknown. Nonetheless, among many gene-expression profiles investigated, two were miRNAs: miR-10 (previously associated with CML) and miR-146b (previously associated with fibrosis). MiR-10 was not associated with disease subtypes, fibrosis, or age. MiR-146b, on the other hand, showed lower expression levels in most pediatric samples when compared to adult counterparts, but no clear associations were found [89]. Other studies evaluating miRNA pathways specifically in childhood CML were not found.

\subsection{Juvenile Myelomonocytic Leukemia}

Juvenile myelomonocytic leukemia (JMML) is a rare myeloid progenitor disorder that occurs in young children with an annual incidence of as much as 1.2 per million children, accounting for less than $3 \%$ of all childhood hematologic malignancies [90].

Patients with JMML respond poorly to chemotherapy and have poor prognosis. The EFS is between $24-54 \%$ after hematopoietic stem-cell transplantation and is less than $10 \%$ without transplant [91]. Somatic defects in RAS, NF1, PTPN11, or CBL are detected in $85 \%$ of patients, evidencing RAS/MAPK-pathway (Rat Sarcoma virus /mitogen-activated protein kinase) activation as an important mechanism in JMML pathogenesis [92].

Aiming to evaluate miRNAs' role in JMML, miR-let-7a-1/miR-let-7f- 1 and the $3^{\prime} U T R$ of NRAS or KRAS were sequenced in BM cells from $10 \mathrm{JMML}$ patients. RAS is a known target of miR-let-7 but, in this report, there was no evidence of any mutations in let-7 or in let-7-binding sites that might lead to its upregulation in JMML [93]. On the other hand, reduced levels of most members of the miR-let-7 miRNA family were evidenced in a novel fetal-like subgroup of JMML patients with LIN28B protein overexpression [94].

Analyses of 20 JMML samples by Ripperger and coworkers through comparative genomic hybridization found two patients with an almost identical partial gain of chromosome 8 , suggesting 
8p11.21q11.21 as a critical region. This band includes 31 protein-coding genes and two noncoding RNAs among which miR-486 is a known regulator of phosphatase and tensin homolog (PTEN) and the transcription factor forkhead box O1 (FOXO1) [95].

In 2013, downregulation of miR-34b was described in JMML patients $(n=17)$ [63], but this association was not confirmed by Liu et al., analyzing a bigger JMML cohort $(n=47)$ [96]. Nonetheless, these authors described high expression levels of miR-183 (13.8 vs. 4.2, $p<0.001)$ with significant linear correlation with monocyte percentage and in samples with PTPN11 mutations [96]. MiR-223 and miR-15a were also found upregulated in JMML BM harboring PTPN11 mutations (11 from 19 analyzed patients), but not those without PTPN11 defects [97].

More recently, distinctive miRNA signatures associated with the PTPN11, KRAS, and NRAS molecular subtypes of JMML were also described. From a panel of miRNAs, miR-630, miR-3195, miR-575, miR-4508, miR-224-5p, miR-320e, miR-494, miR-548ai, miR-222-3p, miR-23a-3p, and miR-338-3p were found upregulated, while miR-150-5p, let-7g-5p, miR-1260a, let-7a-5p, miR-4454, miR-148a-3p, miR-146b-5p, miR-342-3p, let-7f-5p, miR-26a-5p, let-7d-5p, miR-30b-5p, miR-29b-3p, and miR-29a-3p were described as downregulated. Of note, miR-150-5p was found to target STAT5b (Signal transducer and activator of transcription $5 b$ ), and its induced overexpression in mononuclear cells from JMML patients decreased proliferation rates [98].

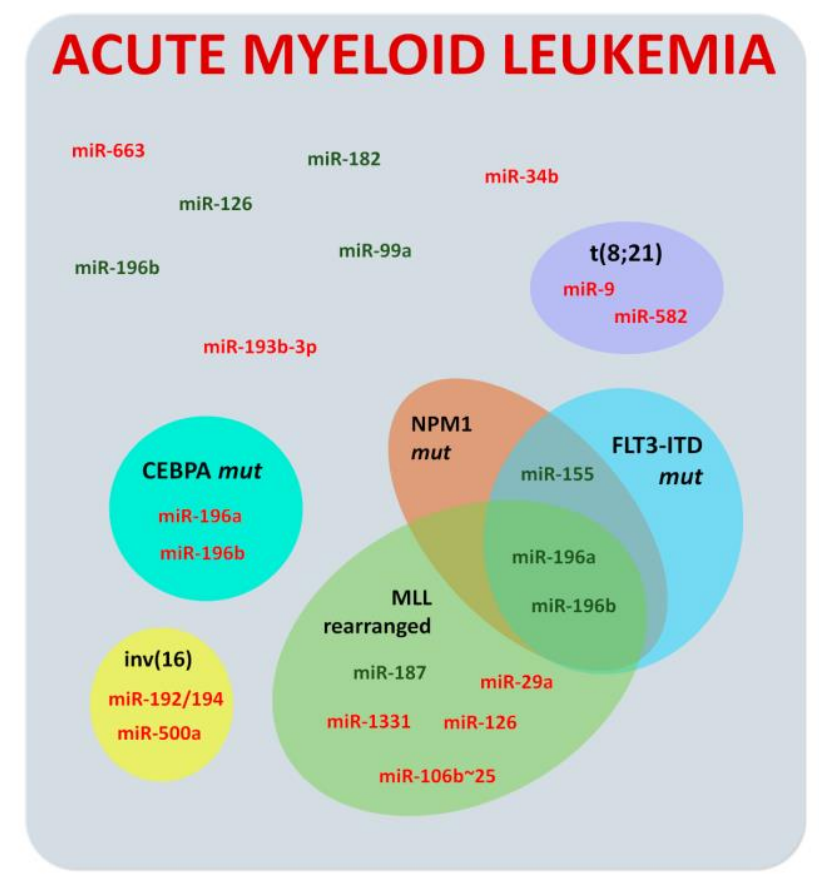

Figure 3. Dysregulated miRNAS in childhood acute myeloid leukemia. Hyperexpressed and hypoexpressed miRNAs in acute lymphoblastic myeloid and cellular/molecular subgroups are denoted in green and red, respectively.

\section{Lymphomas}

Lymphomas stricto sensu comprise any neoplasm of the lymphatic tissue. In the pediatric setting, lymphomas represent the third most common malignancy.

The World Health Organization (WHO) groups lymphomas by cell type and defining phenotypic, molecular, or cytogenetic characteristics [99]. Basically, there are two main categories of lymphoma, Hodgkin (HL) and non-Hodgkin lymphoma (NHL). HL most commonly affects adolescents and accounts for $4-7 \%$ of overall childhood cancer [100], while NHL is more frequently diagnosed in children younger than 15 years of age and represents $7-10 \%$ of pediatric malignancies [101,102]. NHL has a wide range of histological appearances and clinical features at presentation and, despite classification refinement, some groups remain heterogeneous. Nonetheless, Burkitt lymphoma (BL), 
diffuse large B-cell lymphoma (DLBCL), primary mediastinal large B-cell lymphoma (PMLBCL), anaplastic large cell lymphoma (ALCL), and lymphoblastic lymphoma (LL) comprise childhood NHLs [103].

Over the last decade, the pattern of miRNA expression of different types of pediatric lymphomas has been extensively studied. A substantial number of miRNAs have been described as dysregulated and contributing to better classifying this type of tumor, though, for many, their roles in tumor development are still unclear (Figure 4). Moreover, the lack of information about miRNAs in some forms, such as PMLBCL and classical HL, is evident.

\subsection{Burkitt Lymphoma}

BL represents about $30 \%$ of all pediatric NHL and is considered a highly aggressive tumor [102]. The study of miRNA in BL is usually focused on the establishment of miRNA profiles and the understanding of tumor transformation and progression. On this regard, miRNA expression could discriminate BL from other lymphomas, pediatric from adult samples, and Epstein-Barr virus (EBV) BL-positive from negative cases [104-108].

In 2004, miR-155 was the first described as deregulated in lymphoma. This miRNA is encoded by the human BIC gene and it was found overexpressed in pediatric BL. Metzler et al. [102] suggested that this RNA could be acting in co-operation with c-Myc on B-cell transformation. MiR-155 expression induces polyclonal expansion in B-cells, favoring the occurrence of secondary mutations and leading to full transformation [109]. This miRNA has as a direct target SHIP1 (Src homology-2 domain-containing inositol 5-phosphatase 1), whose suppression in hematopoietic cells leads to mieloproliferative diseases [110]. In addition, miR-155 showed low expression in pediatric BL, inversely associated with the downregulation of the nuclear interactor of ARF (ADP-ribosylation factor) and Mdm2 (murine double minute 2) (NIAM, the protein-coding transcript splice variant of TBRG1 locus), a protein with a tumor-suppressor function [111].

It was demonstrated that miR-155 was expressed only in BL EBV-positive cases, which account for $70 \%$ of all pediatric BL $[112,113]$. Secreted vesicles (exosomes) from EBV-positive Raji cells could deliver miR-155 to other recipient cell lines, such as retinal-pigment epithelial cells (ARPE-19), and miR-155 increased transcriptional and translational levels of VEGF-A in ARPE-19 cells [114].

Other studies have also demonstrated a close association between EBV infection and miRNA dysregulation in BL. High levels of miR-155 and miR-146a were found in response to the viral latent membrane protein-1 (LMP1) through NF- $\mathrm{KB}$ (nuclear factor kappa B) modulation, although the precise mechanism is still unclear $[115,116]$. LMP1 seems to stabilize BIC mRNA via p38/MAPK, and the LMP1-BIC axis contributes to EBV-induced lymphomagenesis [117]. Additionally, LMP1 induces miR-34a expression, leading to EBV-transformed cell growth [118]. However, a tumor-suppressor effect of LMP1 has also been described through the upregulation of miR-29b, which represses TCL1 (T-cell leukemia/lymphoma protein 1) and leads to tumor cell-proliferation reduction [119].

Epstein-Barr nuclear antigen 1 (EBNA1) also has a role on BL development by miR-127 induction. This miRNA impairs B-cell differentiation by decreasing BLIMP-1 (PR domain zinc finger protein 1) and XBP-1 (X-box binding protein 1) expression, which leads to BCL-6 overexpression and IRF-4 (interferon regulatory factor 4) downregulation [120]. The presence of the EBV virus determines a profile of miRNAs in pediatric and adults BLs, therefore 28 miRNAs were differentially expressed in positive EBV cases, including EBV-encoded and host miRNAs [107].

During EBV infection, the virus-control miRNAs expression of host cells and expressed two clusters of miRNAs. A member of the miR-BART cluster, EBV-BART-6-3p target interleukin-6 receptor (IL-6R) and impair the immune system [121,122]. Synergistically with EBV-BASRT-6-3p, host cellular miR-142 and miR-197 targeted and reduced expression of IL-6R in Ramos BL cell lines $[123,124]$. Therefore, miRNA detection could be a specific and sensitive tool to recognize EBV vestiges once EBV-negative samples classified by immunohistochemistry demonstrated the presence of EBV-miRNAs, suggesting that EBV might contribute to lymphomagenesis [125]. 
Among the dysregulated miRNAs in $\mathrm{BL}$, there are also those regulated by the NF- $\mathrm{kB}$ pathway and those regulated by c-Myc, transcription factors that regulate cell proliferation, growth, and apoptosis. Among these, miR-23a, miR-26a, miR-29b, miR-30d, miR-146a, miR-146b-5p, miR-155, and miR-221 were found statistically significantly downregulated in BL compared to other lymphomas [126]. In Raji cells, miR-520a was associated with the regulation of the AKT1 (v-akt murine thymoma viral oncogene homolog 1) and NF-kB signaling pathways, and mimics of this miRNA inhibited growth and proliferation, and promoted apoptosis [127].

Alterations on c-Myc expression or function of are one of the most frequent abnormalities in human malignancy; in $\mathrm{BL}$, the recurrent $\mathrm{t}(14 ; 18)$ chromosomal translocation juxtaposes this oncogene to the regulatory elements of the immunoglobulin resulting in the constitutive expression of c-Myc [128]. This activation promotes the expression of cluster miR-17-92 [129], which has a causative role in lymphomagenesis, regulating proapoptotic proteins and cell-cycle regulators [130]. In the p53-mutated BL cell line Raji, c-Myc is an alternative target of Inauhzin (INZ) via miRNA pathways, including miR-24 and miR-34a. INZ is a small molecule that activates p53 and inhibits tumor growth [131]. In fact, De Falco et al. (2015) showed four miRNAs (miR-29a, miR-29b, miR-513a-5p, and miR-628-3p) differentially expressing between MYC translocation-positive and negative BL. These miRNAs targets are involved in gene expression, proliferation, and DNA modification. In MYC translocation-negative, overexpression of DNA methyltransferase (DNMT) was associated with hypoexpression of the miR-29 family [132]. Association between high expression of DNMT1 and decrease in the miR-29 family was observed in a pediatric cohort $(n=71)$, suggesting a methylation control of has-miR-29 [133].

Analysis of known Myc-targeted miRNAs demonstrated significant association between BL with Myc translocation in a cohort composed by $61 \%$ of pediatric BL [104]. Those miRNAs included an upregulated cluster (miR-17-92 and its paralogs miR-18b, miR20b, miR-106a), and a set of downregulated miRNAs (miR-23a, miR-29c, miR-29b, miR150, miR146a). Upregulated miRNAs in BL were expressed at significantly lower levels in normal B cells, T cells and stromal cells, but were noted in BL cell lines (Daudi and Raji). BL cases with high expression of miR-17-92 cluster members showed significantly repression of these target genes in BL [104]. The investigation of the miR-17-92 cluster (miR-17, miR-19a, miR-19b, miR-20, and miR-92 a) expression in pediatric BL showed correlation between the upregulation of miR-17 and miR-20a with a lack of proapoptotic BIM (Bcl-2-like protein 11) expression. MiR-17 was a predictor of shortened OS, and inhibition of this miRNA in Daudi cells induced BIM expression [133].

MiR-26a and miR-28, on the other hand, were found underexpressed in BL. Their ectopic expression reduces proliferation, impairs cell-cycle progression, and increases apoptosis by targeting different proteins $[134,135]$. Another important c-Myc target, miR-150, which targets MYB and survivin, was found downregulated in BL. Overexpression of this miRNA in BL cells reduced proliferation rates and increased apoptosis [136,137].

Moreover, miR-181b, which is located in the intron of the FAMLF (familial acute myelogenous leukemia related factor) gene, showed an inverse correlation with FAMLF expression, and an interaction with its $5^{\prime}$ UTR. Downregulation of FAMLF by miR-181b inhibited cell viability and arrested cell cycle in Raji BL cells [138,139].

Differential miRNA profiles have also been described in endemic Burkitt Lymphoma (eBL), an aggressive germinal center CG cell cancer that represents a subdivision of BL with high incidence in pediatric patients in equatorial Africa. eBL is associated with EBV and Plasmodium falciparum malaria coinfection, and shows c-Myc overexpression [140]. An integrative analysis compared normal germinal center (GC) B cells with eBL and evidenced 49 miRNAs with differential gene expression. Of these, 27 miRNAs were downregulated (including let-7 family members) and 22 upregulated (among them miR-17-92 cluster) in eBL samples. Enrichment of pathways showed the interaction of these miRNAs with marked tumor suppression (PTEN, AXIN1, ATM, NLK), and important proto-oncogenes and tumor-promoting genes as MYC [141]. 
A comparison between eBL jaw- and abdominal-tumor biopsies showed no discernible clustering based on tumor-site designation. MiR-10a-5p was the only miRNA with differential expression, and it was lower in jaw eBL compared to abdominal, and it presented reduced expression in nonsurvivor patients. MiR-10a-5p could target 473 genes, and enrichment of pathways showed its importance in cancer, focal adhesion, EPV infection, and apoptosis pathways [142]. Therefore, in pediatric $\mathrm{BL}, \mathrm{EBV}$ infection and c-Myc translocation promote lymphomagenesis through the deregulation of several miRNAs.

\subsection{Diffuse Large B-Cell Lymphoma}

DLBCL represents $10 \%$ to $20 \%$ of childhood lymphomas and it is more frequently found in children older than 10 years of age [128]. This tumor is divided in two distinct subtypes according to the cell of origin: the activated B cell-like (ABC) and the germinal center B cell-like (GCB) [143], though most pediatric DLBCL patients are diagnosed with the GCB form [144].

The clinical presentation of pediatric DLBCL and BL are very similar. Currently, they are recognized as two different entities; however, in the pediatric group, there is a significant overlap of features resulting in a group of unclassifiable lymphomas. Nonetheless, through microarray technology, different research groups were able to define a collection of distinct miRNAs that constitutes a DLBCL signature $[106,145]$. This analysis also enables us to differentiate ABC from GCB-subtypes.

Ten miRNAs (miR-146b, miR-146a, miR-21, miR-155, miR-500, miR-222, miR-221, miR-363, miR-574, and miR-574*) were found to be more upregulated in ABC than in the GCB lymphoma type, suggesting that the high levels of these miRNAs are not due to tumor malignancy but associated with the cell of origin [146,147]. MiR-155 was one of the first miRNAs found upregulated in ABC-DLBCL $[147,148]$. Its aberrant expression seems to be a consequence of an autocrine stimulation by $\mathrm{TNF} \alpha$ (tumor necrosis factor alfa) rather than chromosomal translocations like in BL tumors [149]. Initially, no correlation with prognosis was found when all DLBCL tumors were considered $[145,150]$; however, when only the $\mathrm{ABC}$ group was examined, high miR-155 expression was associated with better survival rates. In this case, the five-year survival probability changed from $15 \%$ for patients with low $\mathrm{miR}-155$ to $53 \%$ for patients with high miR-155. Moreover, higher expression of miR-222 was also associated with inferior overall and progression-free survival [150].

Other studies later indicated miR-155 and miR-146a as potential diagnostic and prognostic indicators in DLBCL. Patients with low expression of these miRNAs were associated with high complete remission, high overall response rate, and better five-year OS when patients were treated with the R-CHOP protocol (rituximab, cyclophosphamide, doxorubicin, VIN, and PREDS) [151]. Furthermore, in DLBCL patients, higher expression of miR-28, miR-214, miR-339*, and miR-5586 was associated with better outcome, while upregulation of miR-324 was associated with poor prognosis [152].

Although ABC-DLBCL miRNA signatures have been better studied, the expression of few miRNAs was also associated with GCB-DLBCL, such as the amplification of the 17-92 cluster [153] and high levels of miR-106a and miR-181b [154].

Additionally, the role of some of these miRNAs in DLBCL development has been elucidated over the last few years. MiR-125a and miR-25b, for example, are overexpressed in DLBCL and target $T N F \alpha I P 3$, an NF- $\mathrm{KB}$ negative regulator. They participate in a positive self-regulatory loop where miR-125 is also regulated by NF- $\mathrm{kB}$, what is probably an important mechanism to keep the constitutive activation of the NF- $\mathrm{KB}$ pathway in DLBCL pathogenesis [155]. In addition, miR-34a repression was described to cause high-grade transformation of B-cell lymphoma by altering FOXP1 (Forkhead Box P1) expression [156]. Interestingly, mice treated with miR-34a mimics results in a 95\% reduction in DLBCL tumor growth due to its strong proapoptotic properties, suggesting an alternative therapeutic strategy [157]. 


\subsection{Primary Mediastinal Large B-Cell Lymphoma}

PMLBCL was first described in the 1980s and is considered a distinct clinicopathologic entity of DLBCL [158]. PMLBCL is characterized by a rapidly growing mediastinal mass that arises from mature thymic medulla B-cells, frequently accompanied by local invasiveness and occasionally with distant metastasis. Uncommon, but not rare, this clinicopathological entity occurs more often in young adult females [159] and constitutes $2-3 \%$ of all $\mathrm{N}$ and $6-10 \%$ of all diffuse large-cell lymphomas $[160,161]$.

Recently, a large population-based study was able to estimate the incidence of PMLBCL. Based on slightly more than 400 patients in the United States, the annual incidence rate was estimated at 0.4 per million. Females had significantly higher incidence than males (ratio 3:1) and the peak of occurrence was recognized at 30-39 years. The five-year survival rate of $85 \%$ and prognosis were also reduced with advancing age [162].

In patients aged $<18$ years (22/451 cases), PMLBCL incidence was $4.9 \%$ [162]. Other reports, in which young patients showed inferior outcomes, compared adult counterparts or children with other B-NHL histological subtypes, with EFS rates ranging between 70\% and 80\% [163-167].

In the literature, there are few studies on miRNA expression profiles in PMLBCL. The first report was given by Kluiver et al. [168], who showed positivity for BIC and miR-155 in one cell line and eight PMLBCL samples derived from a tissue bank. Later, Iqbal et al. [104] described an miRNA signature that allowed the distinction between PMLBCL from other DLBCL, including upregulation of miR-193b and miR-365, and underexpression of miR-629, miR-423-5p, and miR-15a. Higher levels of miR-92a were also described as a classifier of PMBLBCL [169]. Moreover, a recent study by Malpeli et al. [170] showed that the polycistron miR-17-92 cluster, miR-29 family, miR-150, and miR-497 had the highest power of discrimination between B-cell NHL types, though only eight PMLBCL samples were included. Nonetheless, none of these studies gave any specific details about pediatric samples, and the mean age of patients was always reported above 27 years old.

\subsection{Anaplastic Large-Cell Lymphoma}

Anaplastic large-cell lymphoma (ALCL) is an intermediate grade NHL and accounts for approximately $10 \%$ of pediatric NHL [171]. Most pediatric ALCL present the chromosomal translocation $\mathrm{t}(2 ; 5)(\mathrm{p} 23 ; \mathrm{q} 35)$. In $80 \%$ of cases, that translocation results in the expression of a fusion gene called NPM-ALK that encodes a potent oncogenic tyrosine kinase [172].

Several miRNAs have been described as promoting this neoplasia and they seem to express and act differently in $\mathrm{ALK}^{+}$and $\mathrm{ALK}^{-}$tumors and cell lines $[173,174]$. The suggested signature for $\mathrm{ALK}^{+}$cells includes seven miRNA, five of them being upregulated (miR-512*, miR-886, miR-886*, miR-708, and miR-135b) and two downregulated (miR-146a and miR-155). High expression of miR-886 and miR-886* seems to be related with higher AKT expression, since treatment with AKT inhibitors leads to a reduction on these miRNAs levels. It has been shown that miR-886 might act deregulating apoptosis by targeting the proapoptotic gene $B A X$ [173]. Furthermore, miR-16 is downregulated in $\mathrm{AKT}^{+}$, resulting in VEGF expression, tumor growth, and angiogenesis [175].

Besides the above-mentioned miRNAs, the 17-92 cluster has also been found overexpressed in $\mathrm{AKT}^{+}$ALCL [176]. These miRNAs are transcriptionally regulated by STAT3, a major substrate for ALK, and promote survival and growth of this tumor. Among the known targets of this cluster, BIM and TGF $\beta$ RII have been described. An autoregulatory loop between STAT3 and miR-17-92 was also characterized, suggesting an involvement of this cluster in the pathogenesis of this tumor [177].

Conversely, miR-155 showed low expression in ALCL ALK ${ }^{+}$tumors and cell lines, and its inhibition is mediated by methylation. SR278 transfection (pediatric ALCL ALK-positive cells) with pre-miR-155 reduced expression levels of miR-155 targets (C/EBP $\beta$, SOCS1) by binding sites in their $3^{\prime}$-UTR. The action of miR-155 in the immune system was demonstrated through reducing IL- 8 and IL-22 transcript levels [178]. C/EBP $\beta$ downregulation evidenced the role of this transcription factor in miRNA regulation, mainly miR-181a*, miR-181, and miR-203. MiR-181a showed low expression 
in $\mathrm{ALK}^{+}$ALCL cases; this miRNA coordinates T-cell differentiation and modulates TCR antigen expression, being involved in innate and adaptive immune response [174].

MiR-29a was found remarkably reduced in $\mathrm{ALK}^{+}$when compared to ALK-ALCL, where it regulates MCL-1, contributing with apoptosis blockage [179]. Moreover, ALK knockdown results in increased miR-96 levels, while miR-96 overexpression leads to a reduction in ALK protein levels and decreases cell viability and growth, reinforcing the hypothesis that ALK sustains its own expression by exerting a reciprocal negative feedback loop that hinders the expression of miRNAs [180]. ALK-positive cells showed low levels of miR-146a, miR-29c, miR-29b, miR-29a, miR-22, miR-101, miR-150, and miR-125b, while miR-20b was upregulated [176].

The translocation and activity of NPM-ALK are responsible for miR-150 and miR-125b silencing in cell lines, mediated by DNMT1-dependent activity [181,182]. Inhibition of DNMT1 binding to the MIR125B1 promoter decreased BAK1 expression, an miR-125b target. Mir-125b repression and increase of BAK1 is correlated with early relapse in human ALK ${ }^{+}$ALCL biopsies [182]. Conversely, miR-101 is found downregulated in both types of ALCL, but, because it targets the mammalian/mechanistic target of the rapamycin (mTOR) pathway, its forced expression only affects $\mathrm{ALK}^{+}$cell growth [176].

\subsection{Lymphoblastic Lymphoma}

LL is a rare neoplasm of immature cells committed to the B (B-LBL)- or T-cell lineage (T-LBL) that accounts for approximately $2 \%$ of all lymphomas. The annual incidence in children $(<15$ years $)$ is 3.6 per 100,000, which is then reduced to 0.8 in people older than 25 years old [183]. Studies about the role of miRNAs on this form of lymphoma are scarce and are summarized as follows.

\subsubsection{B-Cell Lymphoblastic Lymphoma}

B-LBL typically affects children younger than six years, but is also encountered in older children and in adult populations [184]. B-LBL tumor cells are virtually always positive for B-cell markers CD19, $\mathrm{CD} 79 \mathrm{a}$, and CD22, and may be associated with the presence of leukemia rearrangements such as those involving ETV6, MLL, or ABL1 [183]. Thus, even though lymph nodes and extranodal sites, such as skin, bone, and soft tissue, are frequently involved, this rare NHL is considered a lymphomatous variant of ALL and is often treated with leukemia-like regimens [183].

As a result, over the last years, high priority has been given to the identification of biological/prognostic features of T-LBL to allow either risk stratification or treatment planning.

\subsubsection{T-Cell Lymphoblastic Lymphoma}

T-LBL represents $30 \%$ of pediatric NHL [185]. The downregulation of miR-193b in T-LBL was first associated with the activation of the GLI/hedgehog pathway promoting cell survival and proliferation by enhancing SMO (smoothened) expression [186]. Later, this miRNA with miR-196b were found involved in the regulation of the PDGF (platelet-derived growth factor) signaling pathway. In addition, miR-221 was specifically found upregulated in T-LBL directly targeting CDKN1B, a cell-cycle regulator [187]. MiR-22, miR-125a, and miR-125b were also identified as upregulated in T-LBL, and seem to have a role on the maintenance of hematopoietic cells contributing to their proliferation and self-renewal abilities [187].

In a cohort with $52 \%$ of T-LBL pediatric samples, upregulation of miR-17 and miR-19 and positive MYC protein was associated with unfavorable prognosis. MYC is known to regulate the miR-17-92 cluster. Cox proportional hazard models showed that miR-17, miR-19, and MYC overexpression were independent poor prognostic factors [188]. MiR-241 is upregulated in T-LBL tissue and a direct target of a long noncoding RNA MEG3 (maternally expressed 3). Overexpression of MEG3 inhibits tumor growth in vitro and in vivo [189].

Downregulation of miR-374b was associated with worse overall survival and increased risk in T-LBL samples. MiR-374b inhibited proliferation and promoted apoptosis in a pediatric T-LBL cell line (SUP-T1) by repressing AKT1 and Wnt-16 [190]. Moreover, upregulation of miR-221-3p and 
miR-222-3p, and downregulation of miR-203a and miR-205-5p, miR-200a-3p, and miR-375 have shown to play important roles in T-LBLs by dysregulating in the CDKN1C/E2F1/TP53 axis [191].

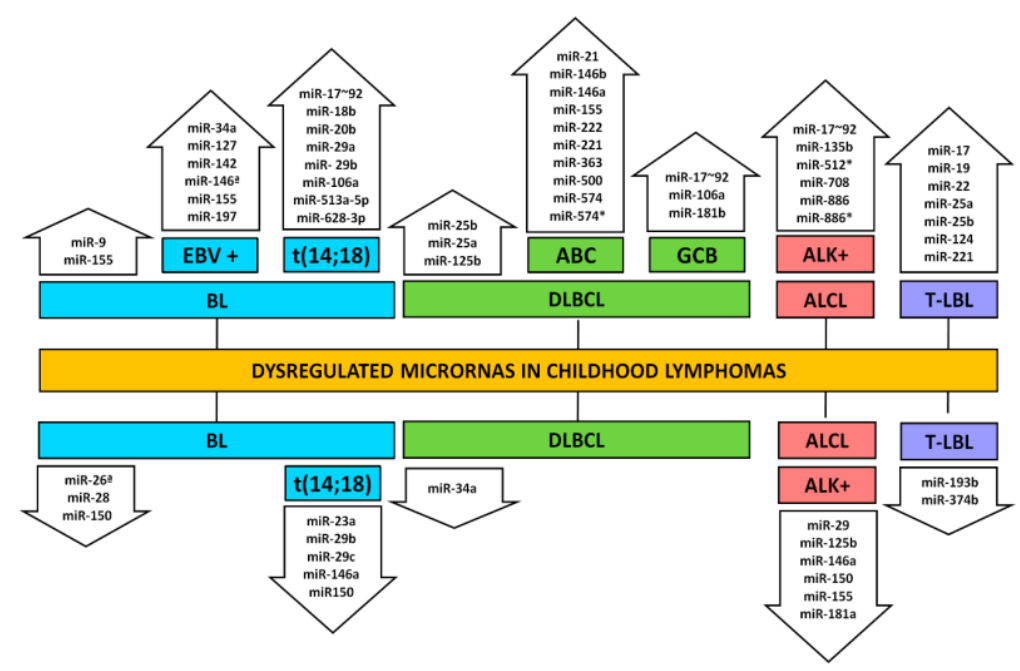

Figure 4. Dysregulated miRNAS in childhood lymphomas. Upside and downside arrows designate hyperexpressed and hypoexpressed miRNAs, respectively; Burkitt lymphoma (BL) (including Epstein-Bar virus and $\mathbf{t}(14 ; 18)$ positive cases), diffuse large B-cell lymphoma (DLBCL) (including activated B-cell-like and germinal center B-cell-like subtypes), anaplastic large-cell lymphoma (ALCL) (including the $\mathrm{ALK}^{+}$subtype), and lymphoblastic T-cell lymphoma (T-LBL).

\subsection{Hodgkin's Lymphoma}

Hodgkin lymphoma (HL) is characterized by multinucleated giant cells (Hodgkin/Reed-Sternberg cells, H/RS) or large mononuclear cell variants (lymphocytic and histiocytic cells) (representing 1\% of the tumor) in a background of inflammatory cells that include lymphocytes, histiocytes, neutrophils, eosinophils, plasma cells, and fibroblasts [192]. The annual incidence of HL is 2-3 cases per 100,000 in Europe and the USA, with a bimodal peak, with young adults aged 15-34 being the most affected, followed by those aged 60 and older [193]. HL accounts for $5 \%$ to $6 \%$ of all childhood cancer and is one of the most curable forms [194]. The five-year EFS in childhood and adolescence exceeds $90 \%$ for patients with early-stage and $70 \%$ to $80 \%$ for those with advanced-stage disease [195].

Over the last decade, efforts have been made in order to identify miRNAs as biomarkers for the refinement of diagnosis and therapy of HL; even so, information is still limited. Some miRNAs have been described as dysregulated in adult samples (mean age 29 years old) by different groups [196-198]. MiR-25, miR-30a/d, miR-26b, miR-182, miR-186, miR-140*, and miR-125a [199], or miR-34a-5p, miR-146a-5p, miR-93-5p, miR-20a-5p, miR-339-3p, miR-324-3p, miR-372, miR-127-3p, miR-155-5p, miR-320a, and miR-370 [200], for instance, have been described as upregulated in tumor samples. Concomitantly, miR-23a, miR-122, miR-93, and miR-144 [199], miR-582-3p, miR-525-3p, miR-448, miR-512-3p, miR-642a-5p, miR-876-5p, miR-532-3p, miR-654-5p, miR-128, miR-145-5p, miR-15b-5p, miR-328, and miR-660-5p were designated as downregulated [200]. Other studies that are based on a limited number of samples have no information about age [201], used data miming [202], or are centered on different cell lines that are all of adult origin [203-206]. Thus, so far, there is no information about dysregulated miRNAs in the pediatric setting.

\section{MiRNAs in Clinics}

\subsection{Circulating MiRNAs as Biomarkers}

The pursuit for noninvasive tools for the diagnosis and management of cancer has long encouraged the interest of researchers into the field of circulating nucleic acids. Compelling evidence 
has shown that genetic and epigenetic cancer markers are also measureable in the plasma and serum of cancer patients and may be useful as a tool for early detection, diagnosis, and follow-up [207,208].

Recently, extracellular circulating miRNAs were detected in secreted membrane vesicles (exosomes), blood serum, and other body fluids. This discovery suggests that miRNAs play a role in intracellular communication in both a paracrine and endocrine manner [209]. Dysregulated expression of miRNAs is implicated in tumorigenesis; therefore, functional characterization of these miRNAs in cancer has received more attention in identifying promising diagnostic and/or prognostic biomarkers. On this regard, MiRNAs are ideal candidates due to their unique expression patterns associated with disease-stage stability and their stability in plasma, easy detection, and recovery [210].

After the first description of circulating miRNAs in lymphoma patients, a significant increase in the number of studies appeared [207], but the amount of research of pediatric cases is smaller than their adult counterparts.

In ALL, a few circulating miRNAs were recently described, and among them miR-146a. Significant higher median levels of miR-100, miR-196a, and miR-146a were reported in blood samples of affected children compared to controls, but the diagnostic efficacy for miR-146a analysis presented superior sensitivity and specificity [211]. These same authors recently reported the significant increased expression of circulating miR-125b-1 and low levels of miR-203 in serum samples from untreated newly diagnosed children with ALL $(n=43)$, as detected by quantitative RT-PCR analysis [212]. They also showed higher levels of miR-125b-1 in T-ALL samples as compared to other ALL phenotypes [212]. More recently, circulating miR-652-3p was found downregulated in serum from ALL patients and levels reported as restored when patients attained in complete remission [47].

In AML patients, Fayyad-Kazan et al. [213] analyzed serum samples from a large cohort of newly diagnosed patients and compared them to normal samples from adult donors. After a two-phase selection and validation process, let-7d, miR-150, miR-339, and miR-342 were found downregulated, while let-7b and miR-523 were upregulated AML compared to control sera [213]. Other results have revealed the presence of two miRNAs, miR-150 and miR-342, significantly downregulated in the plasma of AML patients at diagnosis when compared to healthy controls [214]. Moreover, high serum miR-335 levels were associated with shorter RFS and OS. Furthermore, serum miR-335 and cytogenetic risk were identified as independent prognostic factors for both RFS and OS, suggesting miR-335 as a promising biomarker for pediatric AML [214,215]. Conversely, Zhao and colleagues [216] showed that miR-144 was markedly reduced in both the peripheral blood and bone marrow of AML patients. A similar pattern is commonly observed, miR-34a underexpression in AML patients with intermediate/poor risk cytogenetic and the M5 subtype [217]. More recently, low levels of miR-370 and miR-195 were described in sera of pediatric AML patients and associated with classification M7 subtype, unfavorable karyotype, and shorter RFS and OS [218,219].

In lymphoma, Lawrie et al. [207] showed miR-155, miR-210, and miR-21 in high levels in serum from DLBCL patients compared with healthy controls' sera. Moreover, high miR-21 expression was associated with RFS [207], which was later confirmed by Chen et al. [220] in an independent cohort; thus far, it is the only circulating miRNA in DLBC that has shown consistent results and is now considered a biomarker for diagnosis [221].

More recently, the high levels of miR-155 and miR-22 in plasma from DLBCL patients were associated with shorter overall survival $[222,223]$, while high levels of circulating miR-125b and miR-130a further demonstrated that they were involved in the recurrence, progression, and R-CHOP resistance [224]. Additionally, Khare et al. [199] described increased plasma levels of miR-124 and miR-532-5p, and decreased levels of miR-425, miR-141, miR-145, miR-197, miR-345, miR-424, miR-128, and miR-122 in plasma samples from patients with DLBCL through small-RNA sequencing.

For other lymphoma types, information is restricted to adult cases. MiR-221 has been described as elevated in plasma samples from T-LBL patients, with higher levels associated with a poorer long-term outcome [225]. Overexpression of miR-21 and miR-23a, on the other hand, has been associated with staging, WBC, upregulated serum lactate dehydrogenase (LDH) level, and tumor size $\geq 6 \mathrm{~cm}$ in 
BL, while miR-125b expression had an association with staging and upregulated serum LDH [226]. Additionally, a more recent study identified miR-25, miR-30a/d, miR-26b, miR-182, miR-186, miR-140*, and miR-125a to be upregulated, while miR-23a, miR-122, miR-93, and miR-144 were downregulated in HL [199].

\subsection{Prognostic Use of MiRNAs}

Despite substantial advancement in research and medicine, cancer remains a major public-health problem in our society. Thus, the utility of miRNA expression analysis as diagnostic and prognostic molecular markers is strongly supported. For example, analysis of 217 miRNAs from 334 samples including multiple human cancers provided expression signatures more accurate for cancer-subtype classification than expression-profiling of all known mRNAs does [227]. Additionally, as seen in previous sections, many miRNA dysregulations have also been associated with treatment response (Figure 2). Thereafter, many research groups have shown aberrant-expression profiles of miRNAs in a broad variety of human malignant cancers, especially hematological cancer (Tables S1 and S2). Furthermore, miRNA analysis has some benefits because these molecules are highly resistant to degradation and their expression levels can be obtained in a few hours with small biological samples [9].

\subsection{Therapeutic Use of MiRNAs}

The progress of miRNAs analysis as molecular markers creates hope for personalized cancer treatments by miRNA modulation. Unfortunately, miRNAs are still not druggable, and clinics are far from reality due to a variety of challenges. Nonetheless, local delivery through encapsulation in lipidic or polymer nanoparticles, or ultrasound-mediated microbubble formulations and hyaluronic acid (HA)/protamine sulfate (PS) interpolyelectrolyte complexes, has shown promising results in mice models [228-233]. Viral vectors for delivering miRNAs into cells have also been widely used in preclinical studies; nonetheless, their safety remains controversial mainly because of lack of safety (i.e., lentivirus), off-target effects, or immune responses [234].

So far, only two strategies have entered clinical trials, though none of them involved hematologic cancer. Miravirsen (Satnaris Pharma ${ }^{\circledR}$ ), a locked nucleic acid-modified DNA antisense oligonucleotide that targets the liver-specific miR-122 has demonstrated antiviral activity against hepatitis $C$ and, at phase 2, no dose-limiting adverse events [233,235]. More recently, Mirna Therapeutics Inc. began treating patients with advanced solid tumors with MRX $34^{\circledR}$, a liposomal injection carrying encapsulated miR-34 showing acceptable safety and evidence of antitumor activity in a subset of patients, despite some liposome-related toxicities [236].

\section{Concluding Remarks}

Targeted therapies have distinctly transformed the treatment of cancer over the past decade. The utility of miRNA-expression analysis as diagnostic and prognostic molecular markers is strongly supported and, in the near future, it may impact the treatment of hematological cancer.

Supplementary Materials: Supplementary materials can be found at http:/ / www.mdpi.com/1422-0067/19/9/ 2688/s1.

Author Contributions: J.C.d.O., G.M.R., M.B., K.B.S., J.A.P. and M.S.B. wrote and organized the manuscript. M.S.B. created the figures, and edited and finalized the manuscript. All authors read and approved the final manuscript.

Funding: This research received no external funding.

Conflicts of Interest: The authors declare no conflict of interest.

\section{Abbreviations}

ABC Activated B-cell-like

ALCL Anaplastic Large-Cell Lymphoma

ALL Acute Lymphoblastic Leukemia 


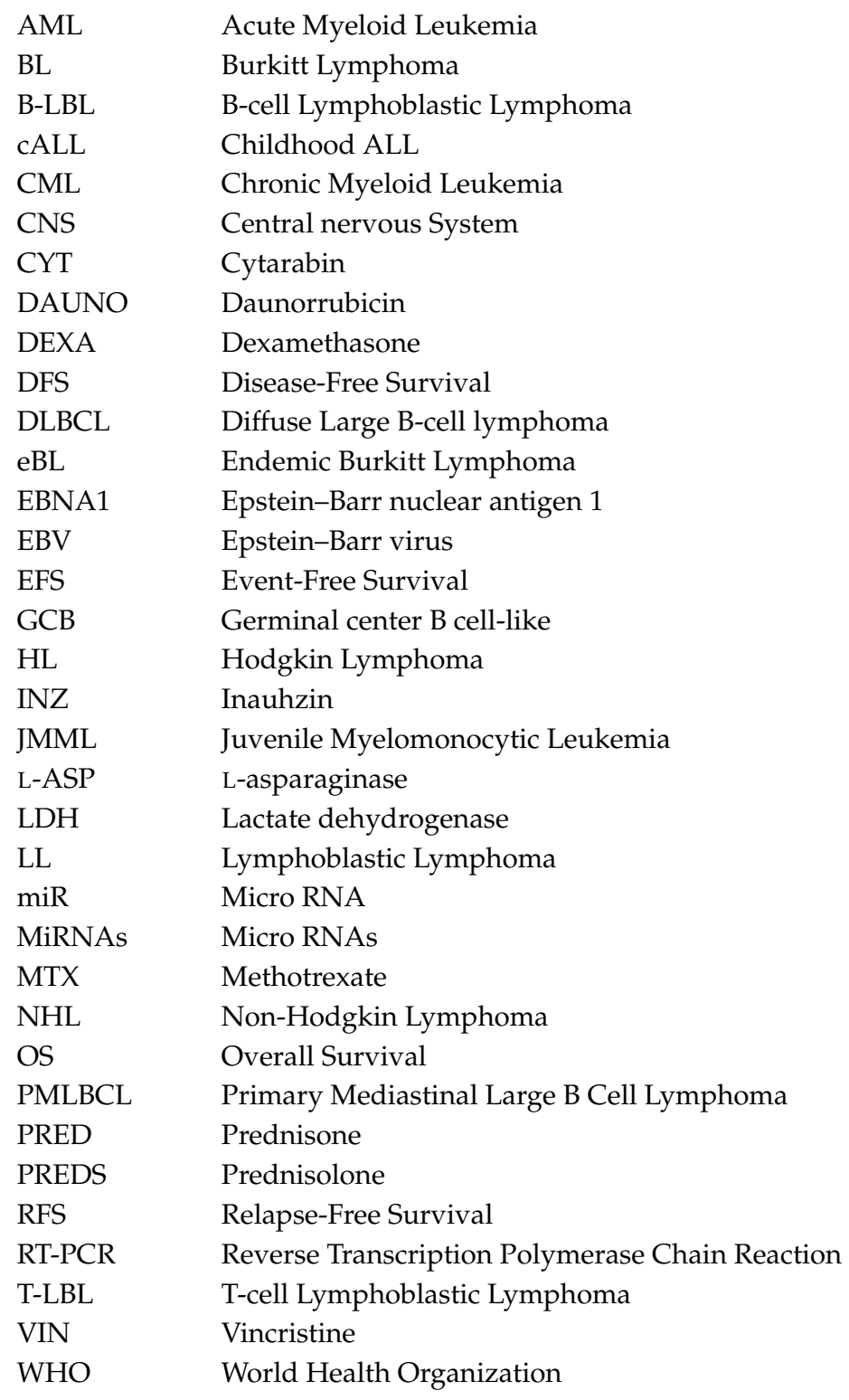

\section{References}

1. Lee, R.C.; Feinbaum, R.L.; Ambros, V. The C. elegans heterochronic gene lin-4 encodes small RNAs with antisense complementarity to lin-14. Cell 1993, 75, 843-854. [CrossRef]

2. Calin, G.A.; Dumitru, C.D.; Shimizu, M.; Bichi, R.; Zupo, S.; Noch, E.; Aldler, H.; Rattan, S.; Keating, M.; Rai, K.; et al. Nonlinear partial differential equations and applications: Frequent deletions and down-regulation of micro-RNA genes miR15 and miR16 at 13q14 in chronic lymphocytic leukemia. Proc. Natl. Acad. Sci. USA 2002, 99, 15524-15529. [CrossRef] [PubMed]

3. Michael, M.Z.; O' Connor, S.M.; van Holst Pellekaan, N.G.; Young, G.P.; James, R.J. Reduced accumulation of specific microRNAs in colorectal neoplasia. Mol. Cancer Res. 2003, 1, 882-891. [PubMed]

4. Calin, G.A.; Sevignani, C.; Dumitru, C.D.; Hyslop, T.; Noch, E.; Yendamuri, S.; Shimizu, M.; Rattan, S.; Bullrich, F.; Negrini, M.; et al. Human microRNA genes are frequently located at fragile sites and genomic regions involved in cancers. Proc. Natl. Acad. Sci. USA 2004, 101, 2999-3004. [CrossRef] [PubMed]

5. Takamizawa, J.; Konishi, H.; Yanagisawa, K.; Tomida, S.; Osada, H.; Endoh, H.; Harano, T.; Yatabe, Y.; Nagino, M.; Nimura, Y.; et al. Reduced Expression of the let-7 MicroRNAs in Human Lung Cancers in Association with Shortened Postoperative Survival Advances in Brief Reduced Expression of the let-7 MicroRNAs in Human Lung Cancers in Association with Shortened Postoperative Survival. Cancer Res. 2004, 64, 3753-3756. [CrossRef] [PubMed] 
6. Calin, G.A.; Liu, C.-G.; Sevignani, C.; Ferracin, M.; Felli, N.; Dumitru, C.D.; Shimizu, M.; Cimmino, A.; Zupo, S.; Dono, M.; et al. MicroRNA profiling reveals distinct signatures in B cell chronic lymphocytic leukemias. Proc. Natl. Acad. Sci. USA 2004, 101, 11755-11760. [CrossRef] [PubMed]

7. MacDonagh, L.; Gray, S.G.; Finn, S.P.; Cuffe, S.; O’Byrne, K.J.; Barr, M.P. The emerging role of microRNAs in resistance to lung cancer treatments. Cancer Treat. Rev. 2015, 41, 160-169. [CrossRef] [PubMed]

8. Sun, X.; Charbonneau, C.; Wei, L.; Chen, Q.; Terek, R.M. miR-181a Targets RGS16 to Promote Chondrosarcoma Growth, Angiogenesis, and Metastasis. Mol. Cancer Res. 2015, 13, 1347-1357. [CrossRef] [PubMed]

9. Kong, Y.W.; Ferland-McCollough, D.; Jackson, T.J.; Bushell, M. microRNAs in cancer management. Lancet Oncol. 2012, 13, e249-e258. [CrossRef]

10. Metayer, C.; Milne, E.; Clavel, J.; Infante-Rivard, C.; Petridou, E.; Taylor, M.; Schüz, J.; Spector, L.G.; Dockerty, J.D.; Magnani, C.; et al. The Childhood Leukemia International Consortium. Cancer Epidemiol. 2013, 37, 336-347. [CrossRef] [PubMed]

11. Amitay, E.L.; Keinan-Boker, L. Breastfeeding and Childhood Leukemia Incidence: A Meta-analysis and Systematic Review. JAMA Pediatr. 2015, 169, e151025. [CrossRef] [PubMed]

12. Madhusoodhan, P.P.; Carroll, W.L.; Bhatla, T. Progress and Prospects in Pediatric Leukemia. Curr. Probl. Pediatr. Adolesc. Health Care 2016, 46, 229-241. [CrossRef] [PubMed]

13. Seth, R.; Singh, A. Leukemias in Children. Indian J. Pediatr. 2015, 82, 817-824. [CrossRef] [PubMed]

14. Pui, C.-H.; Evans, W.E. A 50-year journey to cure childhood acute lymphoblastic leukemia. Semin. Hematol. 2013, 50, 185-196. [CrossRef] [PubMed]

15. Iacobucci, I.; Papayannidis, C.; Lonetti, A.; Ferrari, A.; Baccarani, M.; Martinelli, G. Cytogenetic and molecular predictors of outcome in acute lymphocytic leukemia: Recent developments. Curr. Hematol. Malig. Rep. 2012, 7, 133-143. [CrossRef] [PubMed]

16. Mi, S.; Lu, J.; Sun, M.; Li, Z.; Zhang, H.; Neilly, M.B.; Wang, Y.; Qian, Z.; Jin, J.; Zhang, Y.; et al. MicroRNA expression signatures accurately discriminate acute lymphoblastic leukemia from acute myeloid leukemia. Proc. Natl. Acad. Sci. USA 2007, 104, 19971-19976. [CrossRef] [PubMed]

17. Ju, X.; Li, D.; Shi, Q.; Hou, H.; Sun, N.; Shen, B. Differential microRNA expression in childhood B-cell precursor acute lymphoblastic leukemia. Pediatr. Hematol. Oncol. 2009, 26, 1-10. [CrossRef] [PubMed]

18. Schotte, D.; Chau, J.C.K.; Sylvester, G.; Liu, G.; Chen, C.; van der Velden, V.H.J.; Broekhuis, M.J.C.; Peters, T.C.J.M.; Pieters, R.; den Boer, M.L. Identification of new microRNA genes and aberrant microRNA profiles in childhood acute lymphoblastic leukemia. Leukemia 2009, 23, 313-322. [CrossRef] [PubMed]

19. De Oliveira, J.C.; Scrideli, C.A.; Brassesco, M.S.; Morales, A.G.; Pezuk, J.A.; Queiroz, R.D.P.; Yunes, J.A.; Brandalise, S.R.; Tone, L.G. Differential MiRNA expression in childhood acute lymphoblastic leukemia and association with clinical and biological features. Leuk. Res. 2012, 36, 293-298. [CrossRef] [PubMed]

20. De Oliveira, J.C.; Scrideli, C.A.; Brassesco, M.S.; Yunes, J.A.; Brandalise, S.R.; Tone, L.G. MiR-708-5p is differentially expressed in childhood acute lymphoblastic leukemia but not strongly associated to clinical features. Pediatr. Blood Cancer 2015, 62, 177-178. [CrossRef] [PubMed]

21. Duyu, M.; Durmaz, B.; Gunduz, C.; Vergin, C.; Yilmaz Karapinar, D.; Aksoylar, S.; Kavakli, K.; Cetingul, N.; Irken, G.; Yaman, Y.; et al. Prospective evaluation of whole genome microRNA expression profiling in childhood acute lymphoblastic leukemia. Biomed. Res. Int. 2014, 2014, 967585. [CrossRef] [PubMed]

22. Panagal, M.; Senthil, R.S.K.; Sivakurunathan, P.; Biruntha, M.; Karthigeyan, M.; Gopinathe, V.; Sivakumare, P.; Sekar, D. MicroRNA21 and the various types of myeloid leukemia. Cancer Gene Ther. 2018, 25, 161-166. [CrossRef] [PubMed]

23. Zhang, H.; Luo, X.-Q.; Zhang, P.; Huang, L.-B.; Zheng, Y.-S.; Wu, J.; Zhou, H.; Qu, L.-H.; Xu, L.; Chen, Y.-Q. MicroRNA Patterns Associated with Clinical Prognostic Parameters and CNS Relapse Prediction in Pediatric Acute Leukemia. PLoS ONE 2009, 4, e7826. [CrossRef] [PubMed]

24. Mosakhani, N.; Missiry, M.E.; Vakkila, E.; Knuutila, S.; Vakkila, J. Low Expression of miR-18a as a Characteristic of Pediatric Acute Lymphoblastic Leukemia. J. Pediatr. Hematol. Oncol. 2017, 39, 585-588. [CrossRef] [PubMed]

25. Nabhan, M.; Louka, M.L.; Khairy, E.; Tash, F.; Ali-Labib, R.; El-Habashy, S. MicroRNA-181a and its target Smad 7 as potential biomarkers for tracking child acute lymphoblastic leukemia. Gene 2017, 628, 253-258. [CrossRef] [PubMed] 
26. Fulci, V.; Colombo, T.; Chiaretti, S.; Messina, M.; Citarella, F.; Tavolaro, S.; Guarini, A.; Foà, R.; Macino, G. Characterization of B- and T-lineage acute lymphoblastic leukemia by integrated analysis of MicroRNA and mRNA expression profiles. Genes. Chromosom. Cancer 2009, 48, 1069-1082. [CrossRef] [PubMed]

27. Schotte, D.; De Menezes, R.X.; Moqadam, F.A.; Khankahdani, L.M.; Lange-Turenhout, E.; Chen, C.; Pieters, R.; Den Boer, M.L. MicroRNA characterize genetic diversity and drug resistance in pediatric acute lymphoblastic leukemia. Haematologica 2011, 96, 703-711. [CrossRef] [PubMed]

28. He, Z.; Liao, Z.; Chen, S.; Li, B.; Yu, Z.; Luo, G.; Yang, L.; Zeng, C.; Li, Y. Downregulated miR-17, miR-29c, miR-92a and miR-214 may be related to BCL11B overexpression in T cell acute lymphoblastic leukemia. Asia Pac. J. Clin. Oncol. 2018. [CrossRef] [PubMed]

29. Krzanowski, J.; Madzio, J.; Pastorczak, A.; Tracz, A.; Braun, M.; Tabarkiewicz, J.; Pluta, A.; Młynarski, W.; Zawlik, I. Selected miRNA levels are associated with IKZF1 microdeletions in pediatric acute lymphoblastic leukemia. Oncol. Lett. 2017, 14, 3853-3861. [CrossRef] [PubMed]

30. Gefen, N.; Binder, V.; Zaliova, M.; Linka, Y.; Morrow, M.; Novosel, A.; Edry, L.; Hertzberg, L.; Shomron, N.; Williams, O.; et al. Hsa-mir-125b-2 is highly expressed in childhood ETV6/RUNX1 (TEL/AML1) leukemias and confers survival advantage to growth inhibitory signals independent of p53. Leukemia 2010, 24, 89-96. [CrossRef] [PubMed]

31. Labib, H.A.; Elantouny, N.G.; Ibrahim, N.F.; Alnagar, A.A. Upregulation of microRNA-21 is a poor prognostic marker in patients with childhood B cell acute lymphoblastic leukemia. Hematology 2017, 22, 392-397. [CrossRef] [PubMed]

32. Mavrakis, K.J.; Van Der Meulen, J.; Wolfe, A.L.; Liu, X.; Mets, E.; Taghon, T.; Khan, A.A.; Setty, M.; Setti, M.; Rondou, P.; et al. A cooperative microRNA-tumor suppressor gene network in acute T-cell lymphoblastic leukemia (T-ALL). Nat. Genet. 2011, 43, 673-678. [CrossRef] [PubMed]

33. Mansour, M.R.; Sanda, T.; Lawton, L.N.; Li, X.; Kreslavsky, T.; Novina, C.D.; Brand, M.; Gutierrez, A.; Kelliher, M.A.; Jamieson, C.H.M.; et al. The TAL1 complex targets the FBXW7 tumor suppressor by activating miR-223 in human T cell acute lymphoblastic leukemia. J. Exp. Med. 2013, 210, 1545-1557. [CrossRef] [PubMed]

34. Kumar, V.; Palermo, R.; Talora, C.; Campese, A.F.; Checquolo, S.; Bellavia, D.; Tottone, L.; Testa, G.; Miele, E.; Indraccolo, S.; et al. Notch and NF-kB signaling pathways regulate miR-223/FBXW7 axis in T-cell acute lymphoblastic leukemia. Leukemia 2014, 28, 2324-2335. [CrossRef] [PubMed]

35. Doerrenberg, M.; Kloetgen, A.; Hezaveh, K.; Wössmann, W.; Bleckmann, K.; Stanulla, M.; Schrappe, M.; McHardy, A.C.; Borkhardt, A.; Hoell, J.I. T-cell acute lymphoblastic leukemia in infants has distinct genetic and epigenetic features compared to childhood cases. Genes Chromosom. Cancer 2017, 56, 159-167. [CrossRef] [PubMed]

36. Mesrian Tanha, H.; Mojtabavi Naeini, M.; Rahgozar, S.; Moafi, A.; Honardoost, M.A. Integrative computational in-depth analysis of dysregulated miRNA-mRNA interactions in drug-resistant pediatric acute lymphoblastic leukemia cells: An attempt to obtain new potential gene-miRNA pathways involved in response to treatment. Tumour Biol. 2016, 37, 7861-7872. [CrossRef] [PubMed]

37. Bereza, W.; Szczepanek, J.; Laskowska, J.; Tretyn, A. New Candidate Genes for Lack of Sensitivity to Therapy in Pediatric Leukemias. Curr. Cancer Drug Targets 2017, 17, 333-343. [CrossRef] [PubMed]

38. Cao, L.; Wang, N.; Pan, J.; Hu, S.; Zhao, W.; He, H.; Wang, Y.; Gu, G.; Chai, Y. Clinical significance of microRNA-34b expression in pediatric acute leukemia. Mol. Med. Rep. 2016, 13, 2777-2784. [CrossRef] [PubMed]

39. Nemes, K.; Csóka, M.; Nagy, N.; Márk, Á.; Váradi, Z.; Dankó, T.; Kovács, G.; Kopper, L.; Sebestyén, A. Expression of Certain Leukemia/Lymphoma Related microRNAs and its Correlation with Prognosis in Childhood Acute Lymphoblastic Leukemia. Pathol. Oncol. Res. 2015, 21, 597-604. [CrossRef] [PubMed]

40. Xu, C.; Zheng, Y.; Lian, D.; Ye, S.; Yang, J.; Zeng, Z. Analysis of microRNA expression profile identifies novel biomarkers for non-small cell lung cancer. Tumori 2015, 101, 104-110. [CrossRef] [PubMed]

41. Liang, Y.-N.; Tang, Y.-L.; Ke, Z.-Y.; Chen, Y.-Q.; Luo, X.-Q.; Zhang, H.; Huang, L.-B. MiR-124 contributes to glucocorticoid resistance in acute lymphoblastic leukemia by promoting proliferation, inhibiting apoptosis and targeting the glucocorticoid receptor. J. Steroid Biochem. Mol. Biol. 2017, 172, 62-68. [CrossRef] [PubMed]

42. Azimi, A.; Hagh, M.; Yousefi, B.; Rahnama, M.; Khorrami, A.; Heydarabad, M.; Najafpour, M.; Hallajzadeh, J.; Ghahremani, A. The Effect of Prednisolone on miR 15a and miR16-1 Expression Levels and Apoptosis in Acute Lymphoblastic Leukemia Cell Line: CCRF-CEM. Drug Res. 2016, 66, 432-435. [CrossRef] [PubMed] 
43. Kotani, A.; Ha, D.; Hsieh, J.; Rao, P.K.; Schotte, D.; den Boer, M.L.; Armstrong, S.A.; Lodish, H.F. miR-128b is a potent glucocorticoid sensitizer in MLL-AF4 acute lymphocytic leukemia cells and exerts cooperative effects with miR-221. Blood 2009, 114, 4169-4178. [CrossRef] [PubMed]

44. Yan, J.; Jiang, N.; Huang, G.; Tay, J.L.-S.; Lin, B.; Bi, C.; Koh, G.S.; Li, Z.; Tan, J.; Chung, T.-H.; et al. Deregulated MIR335 that targets MAPK1 is implicated in poor outcome of paediatric acute lymphoblastic leukaemia. Br. J. Haematol. 2013, 163, 93-103. [CrossRef] [PubMed]

45. Umerez, M.; Garcia-Obregon, S.; Martin-Guerrero, I.; Astigarraga, I.; Gutierrez-Camino, A.; Garcia-Orad, A. Role of miRNAs in treatment response and toxicity of childhood acute lymphoblastic leukemia. Pharmacogenomics 2018, 19, 361-373. [CrossRef] [PubMed]

46. Akbari Moqadam, F.; Lange-Turenhout, E.A.M.; Ariës, I.M.; Pieters, R.; den Boer, M.L. MiR-125b, miR-100 and miR-99a co-regulate vincristine resistance in childhood acute lymphoblastic leukemia. Leuk. Res. 2013, 37, 1315-1321. [CrossRef] [PubMed]

47. Jiang, Q.; Lu, X.; Huang, P.; Gao, C.; Zhao, X.; Xing, T.; Li, G.; Bao, S.; Zheng, H. Expression of miR-652-3p and Effect on Apoptosis and Drug Sensitivity in Pediatric Acute Lymphoblastic Leukemia. Biomed. Res. Int. 2018, 2018, 1-10. [CrossRef] [PubMed]

48. Ghodousi, E.S.; Rahgozar, S. MicroRNA-326 and microRNA-200c: Two novel biomarkers for diagnosis and prognosis of pediatric acute lymphoblastic leukemia. J. Cell. Biochem. 2018, 119, 6024-6032. [CrossRef] [PubMed]

49. Gutierrez-Camino, Á.; Umerez, M.; Martin-Guerrero, I.; García de Andoin, N.; Santos, B.; Sastre, A.; Echebarria-Barona, A.; Astigarraga, I.; Navajas, A.; Garcia-Orad, A. Mir-pharmacogenetics of Vincristine and peripheral neurotoxicity in childhood B-cell acute lymphoblastic leukemia. Pharmacogenom. J. 2017. [CrossRef] [PubMed]

50. Gutierrez-Camino, A.; Oosterom, N.; den Hoed, M.A.H.; Lopez-Lopez, E.; Martin-Guerrero, I.; Pluijm, S.M.F.; Pieters, R.; de Jonge, R.; Tissing, W.J.E.; Heil, S.G.; et al. The miR-1206 microRNA variant is associated with methotrexate-induced oral mucositis in pediatric acute lymphoblastic leukemia. Pharmacogenet. Genom. 2017, 27, 303-306. [CrossRef] [PubMed]

51. Wang, S.-M.; Zeng, W.-X.; Wu, W.-S.; Sun, L.-L.; Yan, D. Association between MTHFR microRNA binding site polymorphisms and methotrexate concentrations in Chinese pediatric patients with acute lymphoblastic leukemia. J. Gene Med. 2017, 19, e2990. [CrossRef] [PubMed]

52. Iparraguirre, L.; Gutierrez-Camino, A.; Umerez, M.; Martin-Guerrero, I.; Astigarraga, I.; Navajas, A.; Sastre, A.; Garcia de Andoin, N.; Garcia-Orad, A. MiR-pharmacogenetics of methotrexate in childhood B-cell acute lymphoblastic leukemia. Pharmacogenet. Genom. 2016, 26, 517-525. [CrossRef] [PubMed]

53. Mei, Y.; Gao, C.; Wang, K.; Cui, L.; Li, W.; Zhao, X.; Liu, F.; Wu, M.; Deng, G.; Ding, W.; et al. Effect of microRNA-210 on prognosis and response to chemotherapeutic drugs in pediatric acute lymphoblastic leukemia. Cancer Sci. 2014, 105, 463-472. [CrossRef] [PubMed]

54. Han, B.-W.; Feng, D.-D.; Li, Z.-G.; Luo, X.-Q.; Zhang, H.; Li, X.-J.; Zhang, X.-J.; Zheng, L.-L.; Zeng, C.-W.; Lin, K.-Y.; et al. A set of miRNAs that involve in the pathways of drug resistance and leukemic stem-cell differentiation is associated with the risk of relapse and glucocorticoid response in childhood ALL. Hum. Mol. Genet. 2011, 20, 4903-4915. [CrossRef] [PubMed]

55. Ohyashiki, J.H.; Umezu, T.; Kobayashi, C.; Hamamura, R.S.; Tanaka, M.; Kuroda, M.; Ohyashiki, K. Impact on cell to plasma ratio of miR-92a in patients with acute leukemia: In vivo assessment of cell to plasma ratio of miR-92a. BMC Res. Notes 2010, 3, 347. [CrossRef] [PubMed]

56. Wang, Y.; Li, Z.; He, C.; Wang, D.; Yuan, X.; Chen, J.; Jin, J. MicroRNAs expression signatures are associated with lineage and survival in acute leukemias. Blood Cells. Mol. Dis. 2010, 44, 191-197. [CrossRef] [PubMed]

57. Rodriguez-Otero, P.; Román-Gómez, J.; Vilas-Zornoza, A.; José-Eneriz, E.S.; Martín-Palanco, V.; Rifón, J.; Torres, A.; Calasanz, M.J.; Agirre, X.; Prosper, F. Deregulation of FGFR1 and CDK6 oncogenic pathways in acute lymphoblastic leukaemia harbouring epigenetic modifications of the MIR9 family. Br. J. Haematol. 2011, 155, 73-83. [CrossRef] [PubMed]

58. Kaddar, T.; Chien, W.W.; Bertrand, Y.; Pages, M.P.; Rouault, J.P.; Salles, G.; Ffrench, M.; Magaud, J.P. Prognostic value of miR-16 expression in childhood acute lymphoblastic leukemia relationships to normal and malignant lymphocyte proliferation. Leuk. Res. 2009, 33, 1217-1223. [CrossRef] [PubMed] 
59. Mei, Y.; Li, Z.; Zhang, Y.; Zhang, W.; Hu, H.; Zhang, P.; Wu, M.; Huang, D. Low miR-210 and CASP8AP2 expression is associated with a poor outcome in pediatric acute lymphoblastic leukemia. Oncol. Lett. 2017, 14, 8072-8077. [CrossRef] [PubMed]

60. Piatopoulou, D.; Avgeris, M.; Drakaki, I.; Marmarinos, A.; Xagorari, M.; Baka, M.; Pourtsidis, A.; Kossiva, L.; Gourgiotis, D.; Scorilas, A. Clinical utility of miR-143/miR-182 levels in prognosis and risk stratification specificity of BFM-treated childhood acute lymphoblastic leukemia. Ann. Hematol. 2018, 97, 1169-1182. [CrossRef] [PubMed]

61. Avigad, S.; Verly, I.R.; Lebel, A.; Kordi, O.; Shichrur, K.; Ohali, A.; Hameiri-Grossman, M.; Kaspers, G.J.; Cloos, J.; Fronkova, E.; et al. miR expression profiling at diagnosis predicts relapse in pediatric precursor B-cell acute lymphoblastic leukemia. Genes Chromosom. Cancer 2016, 55, 328-339. [CrossRef] [PubMed]

62. Pulte, D.; Gondos, A.; Brenner, H. Trends in 5- and 10-year Survival After Diagnosis with Childhood Hematologic Malignancies in the United States, 1990-2004. JNCI J. Natl. Cancer Inst. 2008, 100, 1301-1309. [CrossRef] [PubMed]

63. Pigazzi, M.; Manara, E.; Bresolin, S.; Tregnago, C.; Beghin, A.; Baron, E.; Giarin, E.; Cho, E.-C.; Masetti, R.; Rao, D.S.; et al. MicroRNA-34b promoter hypermethylation induces CREB overexpression and contributes to myeloid transformation. Haematologica 2013, 98, 602-610. [CrossRef] [PubMed]

64. Yan-Fang, T.; Jian, N.; Jun, L.; Na, W.; Pei-Fang, X.; Wen-Li, Z.; Dong, W.; Li, P.; Jian, W.; Xing, F.; et al. The promoter of miR-663 is hypermethylated in Chinese pediatric acute myeloid leukemia (AML). BMC Med. Genet. 2013, 14, 74. [CrossRef] [PubMed]

65. Emmrich, S.; Katsman-Kuipers, J.E.; Henke, K.; Khatib, M.E.; Jammal, R.; Engeland, F.; Dasci, F.; Zwaan, C.M.; den Boer, M.L.; Verboon, L.; et al. miR-9 is a tumor suppressor in pediatric AML with t(8;21). Leukemia 2014, 28, 1022-1032. [CrossRef] [PubMed]

66. Obulkasim, A.; Katsman-Kuipers, J.E.; Verboon, L.; Sanders, M.; Touw, I.; Jongen-Lavrencic, M.; Pieters, R.; Klusmann, J.-H.; Zwaan, C.M.; Heuvel-Eibrink, M.M.; et al. Classification of pediatric acute myeloid leukemia based on miRNA expression profiles. Oncotarget 2017, 8, 33078-33085. [CrossRef] [PubMed]

67. Yan, W.; Xu, L.; Sun, Z.; Lin, Y.; Zhang, W.; Chen, J.; Hu, S.; Shen, B. MicroRNA biomarker identification for pediatric acute myeloid leukemia based on a novel bioinformatics model. Oncotarget 2015, 6, 26424-26436. [CrossRef] [PubMed]

68. Xu, L.-H.; Guo, Y.; Cen, J.-N.; Yan, W.-Y.; He, H.-L.; Niu, Y.-N.; Lin, Y.-X.; Chen, C.-S.; Hu, S.-Y. Overexpressed miR-155 is associated with initial presentation and poor outcome in Chinese pediatric acute myeloid leukemia. Eur. Rev. Med. Pharmacol. Sci. 2015, 19, 4841-4850. [PubMed]

69. Ramamurthy, R.; Hughes, M.; Morris, V.; Bolouri, H.; Gerbing, R.B.; Wang, Y.-C.; Loken, M.R.; Raimondi, S.C.; Hirsch, B.A.; Gamis, A.S.; et al. miR-155 expression and correlation with clinical outcome in pediatric AML: A report from Children's Oncology Group. Pediatr. Blood Cancer 2016, 63, 2096-2103. [CrossRef] [PubMed]

70. Bhayadia, R.; Krowiorz, K.; Haetscher, N.; Jammal, R.; Emmrich, S.; Obulkasim, A.; Fiedler, J.; Schwarzer, A.; Rouhi, A.; Heuser, M.; et al. Endogenous Tumor Suppressor microRNA-193b: Therapeutic and Prognostic Value in Acute Myeloid Leukemia. J. Clin. Oncol. 2018, 36, 1007-1016. [CrossRef] [PubMed]

71. Zhu, R.; Zhao, W.; Fan, F.; Tang, L.; Liu, J.; Luo, T.; Deng, J.; Hu, Y. A 3-miRNA signature predicts prognosis of pediatric and adolescent cytogenetically normal acute myeloid leukemia. Oncotarget 2017, 8, 38902-38913. [CrossRef] [PubMed]

72. Xu, L.; Guo, Y.; Yan, W.; Cen, J.; Niu, Y.; Yan, Q.; He, H.; Chen, C.-S.; Hu, S. High level of miR-196b at newly diagnosed pediatric acute myeloid leukemia predicts a poor outcome. EXCLI J. 2017, 16, 197-209. [CrossRef] [PubMed]

73. Wang, Z.; Hong, Z.; Gao, F.; Feng, W. Upregulation of microRNA-375 is associated with poor prognosis in pediatric acute myeloid leukemia. Mol. Cell. Biochem. 2013, 383, 59-65. [CrossRef] [PubMed]

74. Zhu, C.; Wang, Y.; Kuai, W.; Sun, X.; Chen, H.; Hong, Z. Prognostic value of miR-29a expression in pediatric acute myeloid leukemia. Clin. Biochem. 2013, 46, 49-53. [CrossRef] [PubMed]

75. Lim, E.L.; Trinh, D.L.; Ries, R.E.; Wang, J.; Gerbing, R.B.; Ma, Y.; Topham, J.; Hughes, M.; Pleasance, E.; Mungall, A.J.; et al. MicroRNA Expression-Based Model Indicates Event-Free Survival in Pediatric Acute Myeloid Leukemia. J. Clin. Oncol. 2017, 35, 3964-3977. [CrossRef] [PubMed]

76. Danen-van Oorschot, A.A.; Kuipers, J.E.; Arentsen-Peters, S.; Schotte, D.; de Haas, V.; Trka, J.; Baruchel, A.; Reinhardt, D.; Pieters, R.; Michel Zwaan, C.; et al. Differentially expressed miRNAs in cytogenetic and 
molecular subtypes of pediatric acute myeloid leukemia. Pediatr. Blood Cancer 2012, 58, 715-721. [CrossRef] [PubMed]

77. Verboon, L.J.; Obulkasim, A.; de Rooij, J.D.E.; Katsman-Kuipers, J.E.; Sonneveld, E.; Baruchel, A.; Trka, J.; Reinhardt, D.; Pieters, R.; Cloos, J.; et al. MicroRNA-106b 25 cluster is upregulated in relapsed;-rearranged pediatric acute myeloid leukemia. Oncotarget 2016, 7, 48412-48422. [CrossRef] [PubMed]

78. Daschkey, S.; Röttgers, S.; Giri, A.; Bradtke, J.; Teigler-Schlegel, A.; Meister, G.; Borkhardt, A.; Landgraf, P. MicroRNAs Distinguish Cytogenetic Subgroups in Pediatric AML and Contribute to Complex Regulatory Networks in AML-Relevant Pathways. PLoS ONE 2013, 8, e56334. [CrossRef] [PubMed]

79. Zhang, L.; Li, X.; Ke, Z.; Huang, L.; Liang, Y.; Wu, J.; Zhang, X.; Chen, Y.; Zhang, H.; Luo, X. MiR-99a may serve as a potential oncogene in pediatric myeloid leukemia. Cancer Cell Int. 2013, 13, 110. [CrossRef] [PubMed]

80. Yang, J.; Yuan, Y.; Yang, X.; Hong, Z.; Yang, L. Decreased expression of microRNA-122 is associated with an unfavorable prognosis in childhood acute myeloid leukemia and function analysis indicates a therapeutic potential. Pathol. Res. Pract. 2017, 213, 1166-1172. [CrossRef] [PubMed]

81. Liu, X.; Liao, W.; Peng, H.; Luo, X.; Luo, Z.; Jiang, H.; Xu, L. miR-181a promotes G1/S transition and cell proliferation in pediatric acute myeloid leukemia by targeting ATM. J. Cancer Res. Clin. Oncol. 2016, 142, 77-87. [CrossRef] [PubMed]

82. Ding, Q.; Wang, Q.; Ren, Y.; Zhu, H.Q.; Huang, Z. MicroRNA-126 attenuates cell apoptosis by targeting TRAF7 in acute myeloid leukemia cells. Biochem. Cell Biol. 2018. [CrossRef] [PubMed]

83. Sharifi, M.; Fasihi-Ramandi, M.; Sheikhi, A.; Moridnia, A.; Saneipour, M. Apoptosis induction in acute promyelocytic leukemia cells through upregulation of CEBP $\alpha$ by miR-182 blockage. Mol. Biol. Res. Commun. 2018, 7, 25-33. [CrossRef] [PubMed]

84. Chen, Y.; Wang, H.; Kantarjian, H.; Cortes, J. Trends in chronic myeloid leukemia incidence and survival in the United States from 1975 to 2009. Leuk. Lymphoma 2013, 54, 1411-1417. [CrossRef] [PubMed]

85. De la Fuente, J.; Baruchel, A.; Biondi, A.; de Bont, E.; Dresse, M.-F.; Suttorp, M.; Millot, F.; International BFM Group (iBFM). Study Group Chronic Myeloid Leukaemia Committee Managing children with chronic myeloid leukaemia (CML). Br. J. Haematol. 2014, 167, 33-47. [CrossRef] [PubMed]

86. Karalexi, M.A.; Baka, M.; Ryzhov, A.; Zborovskaya, A.; Dimitrova, N.; Zivkovic, S.; Eser, S.; Antunes, L.; Sekerija, M.; Zagar, T.; et al. Survival trends in childhood chronic myeloid leukaemia in Southern-Eastern Europe and the United States of America. Eur. J. Cancer 2016, 67, 183-190. [CrossRef] [PubMed]

87. Shibuta, T.; Honda, E.; Shiotsu, H.; Tanaka, Y.; Vellasamy, S.; Shiratsuchi, M.; Umemura, T. Imatinib induces demethylation of miR-203 gene: An epigenetic mechanism of anti-tumor effect of imatinib. Leuk. Res. 2013, 37, 1278-1286. [CrossRef] [PubMed]

88. Faber, J.; Gregory, R.I.; Armstrong, S.A. Linking miRNA regulation to BCR-ABL expression: The next dimension. Cancer Cell 2008, 13, 467-469. [CrossRef] [PubMed]

89. Hussein, K.; Stucki-Koch, A.; Göhring, G.; Kreipe, H.; Suttorp, M. Increased megakaryocytic proliferation, pro-platelet deposition and expression of fibrosis-associated factors in children with chronic myeloid leukaemia with bone marrow fibrosis. Leukemia 2017, 31, 1540-1546. [CrossRef] [PubMed]

90. Hasle, H.; Kerndrup, G.; Jacobsen, B.B. Childhood myelodysplastic syndrome in Denmark: Incidence and predisposing conditions. Leukemia 1995, 9, 1569-1572. [PubMed]

91. Yoshimi, A.; Kojima, S.; Hirano, N. Juvenile Myelomonocytic Leukemia. Pediatr. Drugs 2010, 12, 11-21. [CrossRef] [PubMed]

92. Stieglitz, E.; Taylor-Weiner, A.N.; Chang, T.Y.; Gelston, L.C.; Wang, Y.-D.; Mazor, T.; Esquivel, E.; Yu, A.; Seepo, S.; Olsen, S.R.; et al. The genomic landscape of juvenile myelomonocytic leukemia. Nat. Genet. 2015, 47, 1326-1333. [CrossRef] [PubMed]

93. Steinemann, D.; Tauscher, M.; Praulich, I.; Niemeyer, C.M.; Flotho, C.; Schlegelberger, B. Mutations in the let-7 binding site-A mechanism of RAS activation in juvenile myelomonocytic leukemia? Haematologica 2010, 95, 1616. [CrossRef] [PubMed]

94. Helsmoortel, H.H.; Bresolin, S.; Lammens, T.; Cavé, H.; Noellke, P.; Caye, A.; Ghazavi, F.; de Vries, A.; Hasle, H.; Labarque, V.; et al. LIN28B overexpression defines a novel fetal-like subgroup of juvenile myelomonocytic leukemia. Blood 2016, 127, 1163-1172. [CrossRef] [PubMed]

95. Ripperger, T.; Tauscher, M.; Praulich, I.; Pabst, B.; Teigler-Schlegel, A.; Yeoh, A.; Göhring, G.; Schlegelberger, B.; Flotho, C.; Niemeyer, C.M.; et al. Constitutional trisomy 8p11.21-q11.21 mosaicism: 
A germline alteration predisposing to myeloid leukaemia. Br. J. Haematol. 2011, 155, 209-217. [CrossRef] [PubMed]

96. Liu, Y.L.; Lensing, S.Y.; Yan, Y.; Cooper, T.M.; Loh, M.L.; Emanuel, P.D. Deficiency of CREB and over expression of miR-183 in juvenile myelomonocytic leukemia. Leukemia 2013, 27, 1585-1588. [CrossRef] [PubMed]

97. Mulero-Navarro, S.; Sevilla, A.; Roman, A.C.; Lee, D.-F.; D’Souza, S.L.; Pardo, S.; Riess, I.; Su, J.; Cohen, N.; Schaniel, C.; et al. Myeloid Dysregulation in a Human Induced Pluripotent Stem Cell Model of PTPN11 -Associated Juvenile Myelomonocytic Leukemia. Cell Rep. 2015, 13, 504-515. [CrossRef] [PubMed]

98. Leoncini, P.P.; Bertaina, A.; Papaioannou, D.; Flotho, C.; Masetti, R.; Bresolin, S.; Menna, G.; Santoro, N.; Zecca, M.; Basso, G.; et al. MicroRNA fingerprints in juvenile myelomonocytic leukemia (JMML) identified miR-150-5p as a tumor suppressor and potential target for treatment. Oncotarget 2016, 7, 55395-55408. [CrossRef] [PubMed]

99. Campo, E.; Swerdlow, S.H.; Harris, N.L.; Pileri, S.; Stein, H.; Jaffe, E.S. The 2008 WHO classification of lymphoid neoplasms and beyond: Evolving concepts and practical applications. Blood 2011, 117, 5019-5032. [CrossRef] [PubMed]

100. Dinand, V.; Arya, L.S. Epidemiology of childhood Hodgkins disease: Is it different in developing countries? Indian Pediatr. 2006, 43, 141-147. [PubMed]

101. Gualco, G.; Klumb, C.E.; Barber, G.N.; Weiss, L.M.; Bacchi, C.E. Pediatric lymphomas in Brazil. Clinics 2010, 65, 1267-1277. [CrossRef] [PubMed]

102. Metzler, M.; Wilda, M.; Busch, K.; Viehmann, S.; Borkhardt, A. High expression of precursor microRNA155/BIC RNA in children with Burkitt lymphoma. Genes Chromosom. Cancer 2004, 39, 167-169. [CrossRef] [PubMed]

103. Sandlund, J.T. Non-Hodgkin Lymphoma in Children. Curr. Hematol. Malig. Rep. 2015, 10, 237-243. [CrossRef] [PubMed]

104. Iqbal, J.; Shen, Y.; Huang, X.; Liu, Y.; Wake, L.; Liu, C.; Deffenbacher, K.; Lachel, C.M.; Wang, C.; Rohr, J.; et al. Global microRNA expression profiling uncovers molecular markers for classification and prognosis in aggressive B-cell lymphoma. Blood 2015, 125, 1137-1145. [CrossRef] [PubMed]

105. Ambrosio, M.R.; Mundo, L.; Gazaneo, S.; Picciolini, M.; Vara, P.S.; Sayed, S.; Ginori, A.; Bello, G.L.; Del Porro, L.; Navari, M.; et al. MicroRNAs sequencing unveils distinct molecular subgroups of plasmablastic lymphoma. Oncotarget 2017, 8, 107356-107373. [CrossRef] [PubMed]

106. Deffenbacher, K.E.; Iqbal, J.; Sanger, W.; Shen, Y.; Lachel, C.; Liu, Z.; Liu, Y.; Lim, M.S.; Perkins, S.L.; $\mathrm{Fu}, \mathrm{K}$; et al. LYMPHOID NEOPLASIA Molecular distinctions between pediatric and adult mature B-cell non-Hodgkin lymphomas identified through genomic profiling. Blood 2012, 119, 3757-3766. [CrossRef] [PubMed]

107. Navari, M.; Etebari, M.; De Falco, G.; Ambrosio, M.R.; Gibellini, D.; Leoncini, L.; Piccaluga, P.P. The presence of Epstein-Barr virus significantly impacts the transcriptional profile in immunodeficiency-associated Burkitt lymphoma. Front. Microbiol. 2015, 6, 556. [CrossRef] [PubMed]

108. Hezaveh, K.; Kloetgen, A.; Bernhart, S.H.; Mahapatra, K.D.; Lenze, D.; Richter, J.; Haake, A.; Bergmann, A.K.; Brors, B.; Burkhardt, B.; et al. ICGC MMML-Seq Project Alterations of microRNA and microRNA-regulated messenger RNA expression in germinal center B-cell lymphomas determined by integrative sequencing analysis. Haematologica 2016, 101, 1380-1389. [CrossRef] [PubMed]

109. Costinean, S.; Zanesi, N.; Pekarsky, Y.; Tili, E.; Volinia, S.; Heerema, N.; Croce, C.M. Pre-B cell proliferation and lymphoblastic leukemia/high-grade lymphoma in E(mu)-miR155 transgenic mice. Proc. Natl. Acad. Sci. USA 2006, 103, 7024-7029. [CrossRef] [PubMed]

110. O'Connell, R.M.; Chaudhuri, A.A.; Rao, D.S.; Baltimore, D. Inositol phosphatase SHIP1 is a primary target of miR-155. Proc. Natl. Acad. Sci. USA 2009, 106, 7113-7118. [CrossRef] [PubMed]

111. Slezak-Prochazka, I.; Kluiver, J.; de Jong, D.; Smigielska-Czepiel, K.; Kortman, G.; Winkle, M.; Rutgers, B.; Koerts, J.; Visser, L.; Diepstra, A.; et al. Inhibition of the miR-155 target NIAM phenocopies the growth promoting effect of miR-155 in B-cell lymphoma. Oncotarget 2016, 7, 2391-2400. [CrossRef] [PubMed]

112. Kluiver, J.; Haralambieva, E.; de Jong, D.; Blokzijl, T.; Jacobs, S.; Kroesen, B.-J.; Poppema, S.; van den Berg, A. Lack of BIC and microRNA miR-155 expression in primary cases of Burkitt lymphoma. Gene. Chromosom. Cancer 2006, 45, 147-153. [CrossRef] [PubMed] 
113. Chabay, P.A.; Preciado, M.V. EBV primary infection in childhood and its relation to B-cell lymphoma development: A mini-review from a developing region. Int. J. Cancer 2013, 133, 1286-1292. [CrossRef] [PubMed]

114. Yoon, C.; Kim, J.; Park, G.; Kim, S.; Kim, D.; Hur, D.Y.; Kim, B.; Kim, Y.S. Delivery of miR-155 to retinal pigment epithelial cells mediated by Burkitt's lymphoma exosomes. Tumor Biol. 2016, 37, 313-321. [CrossRef] [PubMed]

115. Motsch, N.; Pfuhl, T.; Mrazek, J.; Barth, S.; Grässer, F.A. Epstein-Barr virus-encoded latent membrane protein 1 (LMP1) induces the expression of the cellular microRNA miR-146a. RNA Biol. 2007, 4, 131-137. [CrossRef] [PubMed]

116. Cameron, J.E.; Yin, Q.; Fewell, C.; Lacey, M.; McBride, J.; Wang, X.; Lin, Z.; Schaefer, B.C.; Flemington, E.K. Epstein-Barr virus latent membrane protein 1 induces cellular MicroRNA miR-146a, a modulator of lymphocyte signaling pathways. J. Virol. 2008, 82, 1946-1958. [CrossRef] [PubMed]

117. Rahadiani, N.; Takakuwa, T.; Tresnasari, K.; Morii, E.; Aozasa, K. Latent membrane protein-1 of Epstein-Barr virus induces the expression of B-cell integration cluster, a precursor form of microRNA-155, in B lymphoma cell lines. Biochem. Biophys. Res. Commun. 2008, 377, 579-583. [CrossRef] [PubMed]

118. Forte, E.; Salinas, R.E.; Chang, C.; Zhou, T.; Linnstaedt, S.D.; Gottwein, E.; Jacobs, C.; Jima, D.; Li, Q.-J.; Dave, S.S.; et al. The Epstein-Barr virus (EBV)-induced tumor suppressor microRNA MiR-34a is growth promoting in EBV-infected B cells. J. Virol. 2012, 86, 6889-6898. [CrossRef] [PubMed]

119. Anastasiadou, E.; Boccellato, F.; Vincenti, S.; Rosato, P.; Bozzoni, I.; Frati, L.; Faggioni, A.; Presutti, C.; Trivedi, P. Epstein-Barr virus encoded LMP1 downregulates TCL1 oncogene through miR-29b. Oncogene 2010, 29, 1316-1328. [CrossRef] [PubMed]

120. Onnis, A.; Navari, M.; Antonicelli, G.; Morettini, F.; Mannucci, S.; De Falco, G.; Vigorito, E.; Leoncini, L. Epstein-Barr nuclear antigen 1 induces expression of the cellular microRNA hsa-miR-127 and impairing B-cell differentiation in EBV-infected memory B cells. New insights into the pathogenesis of Burkitt lymphoma. Blood Cancer J. 2012, 2, e84. [CrossRef] [PubMed]

121. Kanda, T.; Miyata, M.; Kano, M.; Kondo, S.; Yoshizaki, T.; Iizasa, H. Clustered microRNAs of the Epstein-Barr virus cooperatively downregulate an epithelial cell-specific metastasis suppressor. J. Virol. 2015, 89, 2684-2697. [CrossRef] [PubMed]

122. Ambrosio, M.R.; Navari, M.; Di Lisio, L.; Leon, E.A.; Onnis, A.; Gazaneo, S.; Mundo, L.; Ulivieri, C.; Gomez, G.; Lazzi, S.; et al. The Epstein Barr-encoded BART-6-3p microRNA affects regulation of cell growth and immuno response in Burkitt lymphoma. Infect. Agent. Cancer 2014, 9, 12. [CrossRef] [PubMed]

123. Zhou, L.; Bu, Y.; Liang, Y.; Zhang, F.; Zhang, H.; Li, S. Epstein-Barr Virus (EBV)-BamHI-A Rightward Transcript (BART)-6 and Cellular MicroRNA-142 Synergistically Compromise Immune Defense of Host Cells in EBV-Positive Burkitt Lymphoma. Med. Sci. Monit. 2016, 22, 4114-4120. [CrossRef] [PubMed]

124. Zhang, Y.-M.; Yu, Y.; Zhao, H.-P. EBV-BART-6-3p and cellular microRNA-197 compromise the immune defense of host cells in EBV-positive Burkitt lymphoma. Mol. Med. Rep. 2017, 15, 1877-1883. [CrossRef] [PubMed]

125. Mundo, L.; Ambrosio, M.R.; Picciolini, M.; Lo Bello, G.; Gazaneo, S.; Del Porro, L.; Lazzi, S.; Navari, M.; Onyango, N.; Granai, M.; et al. Unveiling Another Missing Piece in EBV-Driven Lymphomagenesis: EBV-Encoded MicroRNAs Expression in EBER-Negative Burkitt Lymphoma Cases. Front. Microbiol. 2017, 8, 229. [CrossRef] [PubMed]

126. Lenze, D.; Leoncini, L.; Hummel, M.; Volinia, S.; Liu, C.G.; Amato, T.; De Falco, G.; Githanga, J.; Horn, H.; Nyagol, J.; et al. The different epidemiologic subtypes of Burkitt lymphoma share a homogenous micro RNA profile distinct from diffuse large B-cell lymphoma. Leukemia 2011, 25, 1869-1876. [CrossRef] [PubMed]

127. Wang, X.; Wang, P.; Zhu, Y.; Zhang, Z.; Zhang, J.; Wang, H. MicroRNA-520a attenuates proliferation of Raji cells through inhibition of AKT1/NF-kB and PERK/eIF2 $\alpha$ signaling pathway. Oncol. Rep. 2016, 36, 1702-1708. [CrossRef] [PubMed]

128. Allen, C.E.; Kelly, K.M.; Bollard, C.M. Pediatric lymphomas and histiocytic disorders of childhood. Pediatr. Clin. North Am. 2015, 62, 139-165. [CrossRef] [PubMed]

129. O'Donnell, K.A.; Wentzel, E.A.; Zeller, K.I.; Dang, C.V.; Mendell, J.T. c-Myc-regulated microRNAs modulate E2F1 expression. Nature 2005, 435, 839-843. [CrossRef] [PubMed] 
130. Jin, H.Y.; Oda, H.; Lai, M.; Skalsky, R.L.; Bethel, K.; Shepherd, J.; Kang, S.G.; Liu, W.-H.; Sabouri-Ghomi, M.; Cullen, B.R.; et al. MicroRNA-17 92 plays a causative role in lymphomagenesis by coordinating multiple oncogenic pathways. EMBO J. 2013, 32, 2377-2391. [CrossRef] [PubMed]

131. Jung, J.H.; Liao, J.-M.; Zhang, Q.; Zeng, S.; Nguyen, D.; Hao, Q.; Zhou, X.; Cao, B.; Kim, S.-H.; Lu, H. Inauhzin(c) inactivates c-Myc independently of p53. Cancer Biol. Ther. 2015, 16, 412-419. [CrossRef] [PubMed]

132. De Falco, G.; Ambrosio, M.R.; Fuligni, F.; Onnis, A.; Bellan, C.; Rocca, B.J.; Navari, M.; Etebari, M.; Mundo, L.; Gazaneo, S.; et al. Burkitt lymphoma beyond MYC translocation: N-MYC and DNA methyltransferases dysregulation. BMC Cancer 2015, 15, 668. [CrossRef] [PubMed]

133. Robaina, M.C.; Mazzoccoli, L.; Arruda, V.O.; Reis, F.R.D.S.; Apa, A.G.; de Rezende, L.M.M.; Klumb, C.E. Deregulation of DNMT1, DNMT3B and miR-29s in Burkitt lymphoma suggests novel contribution for disease pathogenesis. Exp. Mol. Pathol. 2015, 98, 200-207. [CrossRef] [PubMed]

134. Sander, S.; Bullinger, L.; Klapproth, K.; Fiedler, K.; Kestler, H.A.; Barth, T.F.E.; Möller, P.; Stilgenbauer, S.; Pollack, J.R.; Wirth, T. MYC stimulates EZH2 expression by repression of its negative regulator miR-26a. Blood 2008, 112, 4202-4212. [CrossRef] [PubMed]

135. Ristau, J.; Staffa, J.; Schrotz-King, P.; Gigic, B.; Makar, K.W.; Hoffmeister, M.; Brenner, H.; Ulrich, A.; Schneider, M.; Ulrich, C.M.; et al. Suitability of Circulating miRNAs as Potential Prognostic Markers in Colorectal Cancer. Cancer Epidemiol. Biomark. Prev. 2014, 23, 2632-2637. [CrossRef] [PubMed]

136. Chen, S.; Wang, Z.; Dai, X.; Pan, J.; Ge, J.; Han, X.; Wu, Z.; Zhou, X.; Zhao, T. Re-expression of microRNA-150 induces EBV-positive Burkitt lymphoma differentiation by modulating c-Myb in vitro. Cancer Sci. 2013, 104, 826-834. [CrossRef] [PubMed]

137. Wang, M.; Yang, W.; Li, M.; Li, Y. Low expression of miR-150 in pediatric intestinal Burkitt lymphoma. Exp. Mol. Pathol. 2014, 96, 261-266. [CrossRef] [PubMed]

138. Chen, W.L.; Luo, D.F.; Gao, C.; Ding, Y.; Wang, S.Y. The consensus sequence of FAMLF alternative splice variants is overexpressed in undifferentiated hematopoietic cells. Braz. J. Med. Biol. Res. 2015, 48, 603-609. [CrossRef] [PubMed]

139. Li, J.G.; Ding, Y.; Huang, Y.M.; Chen, W.L.; Pan, L.L.; Li, Y.; Chen, X.L.; Chen, Y.; Wang, S.Y.; Wu, X.N. FAMLF is a target of miR-181b in Burkitt lymphoma. Braz. J. Med. Biol. Res. 2017, 50. [CrossRef] [PubMed]

140. Hecht, J.L.; Aster, J.C. Molecular Biology of Burkitt's Lymphoma. J. Clin. Oncol. 2000, 18, 3707-3721. [CrossRef] [PubMed]

141. Oduor, C.I.; Kaymaz, Y.; Chelimo, K.; Otieno, J.A.; Ong'echa, J.M.; Moormann, A.M.; Bailey, J.A. Integrative microRNA and mRNA deep-sequencing expression profiling in endemic Burkitt lymphoma. BMC Cancer 2017, 17, 761. [CrossRef] [PubMed]

142. Oduor, C.I.; Movassagh, M.; Kaymaz, Y.; Chelimo, K.; Otieno, J.; Ong'echa, J.M.; Moormann, A.M.; Bailey, J.A. Human and Epstein-Barr Virus miRNA Profiling as Predictive Biomarkers for Endemic Burkitt Lymphoma. Front. Microbiol. 2017, 8, 501. [CrossRef] [PubMed]

143. Alizadeh, A.A.; Eisen, M.B.; Davis, R.E.; Ma, C.; Lossos, I.S.; Rosenwald, A.; Boldrick, J.C.; Sabet, H.; Tran, T.; $\mathrm{Yu}, \mathrm{X}$.; et al. Distinct types of diffuse large B-cell lymphoma identified by gene expression profiling. Nature 2000, 403, 503-511. [CrossRef] [PubMed]

144. Oschlies, I.; Klapper, W.; Zimmermann, M.; Krams, M.; Wacker, H.-H.; Burkhardt, B.; Harder, L.; Siebert, R.; Reiter, A.; Parwaresch, R. Diffuse large B-cell lymphoma in pediatric patients belongs predominantly to the germinal-center type B-cell lymphomas: A clinicopathologic analysis of cases included in the German BFM (Berlin-Frankfurt-Munster) Multicenter Trial. Blood 2006, 107, 4047-4052. [CrossRef] [PubMed]

145. Roehle, A.; Hoefig, K.P.; Repsilber, D.; Thorns, C.; Ziepert, M.; Wesche, K.O.; Thiere, M.; Loeffler, M.; Klapper, W.; Pfreundschuh, M.; et al. MicroRNA signatures characterize diffuse large B-cell lymphomas and follicular lymphomas. Br. J. Haematol. 2008, 142, 732-744. [CrossRef] [PubMed]

146. Lawrie, C.H.; Soneji, S.; Marafioti, T.; Cooper, C.D.O.; Palazzo, S.; Paterson, J.C.; Cattan, H.; Enver, T.; Mager, R.; Boultwood, J.; et al. Microrna expression distinguishes between germinal center B cell-like and activated B cell-like subtypes of diffuse large B cell lymphoma. Int. J. Cancer 2007, 121, 1156-1161. [CrossRef] [PubMed]

147. Eis, P.S.; Tam, W.; Sun, L.; Chadburn, A.; Li, Z.; Gomez, M.F.; Lund, E.; Dahlberg, J.E. Accumulation of miR-155 and BIC RNA in human B cell lymphomas. Proc. Natl. Acad. Sci. USA 2005, 102, 3627-3632. [CrossRef] [PubMed] 
148. Rai, D.; Karanti, S.; Jung, I.; Dahia, P.L.M.; Aguiar, R.C.T. Coordinated expression of microRNA-155 and predicted target genes in diffuse large B-cell lymphoma. Cancer Genet. Cytogenet. 2008, 181, 8-15. [CrossRef] [PubMed]

149. Pedersen, I.M.; Otero, D.; Kao, E.; Miletic, A.V.; Hother, C.; Ralfkiaer, E.; Rickert, R.C.; Gronbaek, K.; David, M. Onco-miR-155 targets SHIP1 to promote TNFalpha-dependent growth of B cell lymphomas. EMBO Mol. Med. 2009, 1, 288-295. [CrossRef] [PubMed]

150. Jung, I.; Aguiar, R.C.T. MicroRNA-155 expression and outcome in diffuse large B-cell lymphoma. Br. J. Haematol. 2009, 144, 138-140. [CrossRef] [PubMed]

151. Zhong, H.; Xu, L.; Zhong, J.-H.; Xiao, F.; Liu, Q.; Huang, H.-H.; Chen, F.-Y. Clinical and prognostic significance of miR-155 and miR-146a expression levels in formalin-fixed/paraffin-embedded tissue of patients with diffuse large B-cell lymphoma. Exp. Ther. Med. 2012, 3, 763-770. [CrossRef] [PubMed]

152. Lim, E.L.; Trinh, D.L.; Scott, D.W.; Chu, A.; Krzywinski, M.; Zhao, Y.; Robertson, A.G.; Mungall, A.J.; Schein, J.; Boyle, M.; et al. Comprehensive miRNA sequence analysis reveals survival differences in diffuse large B-cell lymphoma patients. Genome Biol. 2015, 16, 18. [CrossRef] [PubMed]

153. Lenz, G.; Wright, G.W.; Emre, N.C.T.; Kohlhammer, H.; Dave, S.S.; Davis, R.E.; Carty, S.; Lam, L.T.; Shaffer, A.L.; Xiao, W.; et al. Molecular subtypes of diffuse large B-cell lymphoma arise by distinct genetic pathways. Proc. Natl. Acad. Sci. USA 2008, 105, 13520-13525. [CrossRef] [PubMed]

154. Tan, L.P.; Wang, M.; Robertus, J.-L.; Schakel, R.N.; Gibcus, J.H.; Diepstra, A.; Harms, G.; Peh, S.-C.; Reijmers, R.M.; Pals, S.T.; et al. miRNA profiling of B-cell subsets: Specific miRNA profile for germinal center B cells with variation between centroblasts and centrocytes. Lab. Investig. 2009, 89, 708-716. [CrossRef] [PubMed]

155. Kim, S.-W.; Ramasamy, K.; Bouamar, H.; Lin, A.-P.; Jiang, D.; Aguiar, R.C.T. MicroRNAs miR-125a and miR-125b constitutively activate the NF- $\mathrm{B}$ pathway by targeting the tumor necrosis factor alpha-induced protein 3 (TNFAIP3, A20). Proc. Natl. Acad. Sci. USA 2012, 109, 7865-7870. [CrossRef] [PubMed]

156. Craig, V.J.; Cogliatti, S.B.; Imig, J.; Renner, C.; Neuenschwander, S.; Rehrauer, H.; Schlapbach, R.; Dirnhofer, S.; Tzankov, A.; Müller, A. Myc-mediated repression of microRNA-34a promotes high-grade transformation of B-cell lymphoma by dysregulation of FOXP1. Blood 2011, 117, 6227-6236. [CrossRef] [PubMed]

157. Craig, V.J.; Tzankov, A.; Flori, M.; Schmid, C.A.; Bader, A.G.; Müller, A. Systemic microRNA-34a delivery induces apoptosis and abrogates growth of diffuse large B-cell lymphoma in vivo. Leukemia 2012, 26, 2421-2424. [CrossRef] [PubMed]

158. Lichtenstein, A.K.; Levine, A.; Taylor, C.R.; Boswell, W.; Rossman, S.; Feinstein, D.I.; Lukes, R.J. Primary mediastinal lymphoma in adults. Am. J. Med. 1980, 68, 509-514. [CrossRef]

159. Martelli, M.; Ferreri, A.; Di Rocco, A.; Ansuinelli, M.; Johnson, P.W.M. Primary mediastinal large B-cell lymphoma. Crit. Rev. Oncol. Hematol. 2017, 113, 318-327. [CrossRef] [PubMed]

160. Cazals-Hatem, D.; Lepage, E.; Brice, P.; Ferrant, A.; d'Agay, M.F.; Baumelou, E.; Brière, J.; Blanc, M.; Gaulard, P.; Biron, P.; et al. Primary mediastinal large B-cell lymphoma. A clinicopathologic study of 141 cases compared with 916 nonmediastinal large B-cell lymphomas, a GELA ("Groupe d'Etude des Lymphomes de l'Adulte") study. Am. J. Surg. Pathol. 1996, 20, 877-888. [CrossRef] [PubMed]

161. Falini, B.; Venturi, S.; Martelli, M.; Santucci, A.; Pileri, S.; Pescarmona, E.; Giovannini, M.; Mazza, P.; Martelli, M.F.; Pasqualucci, L.; et al. Mediastinal large B-cell lymphoma: Clinical and immunohistological findings in 18 patients treated with different third-generation regimens. Br. J. Haematol. 2008, 89, 780-789. [CrossRef]

162. Liu, P.-P.; Wang, K.-F.; Xia, Y.; Bi, X.-W.; Sun, P.; Wang, Y.; Li, Z.-M.; Jiang, W.-Q. Racial patterns of patients with primary mediastinal large B-cell lymphoma. Medicine 2016, 95, e4054. [CrossRef] [PubMed]

163. Lones, M.A.; Perkins, S.L.; Sposto, R.; Kadin, M.E.; Kjeldsberg, C.R.; Wilson, J.F.; Cairo, M.S. Large-cell lymphoma arising in the mediastinum in children and adolescents is associated with an excellent outcome: A Children's Cancer Group report. J. Clin. Oncol. 2000, 18, 3845-3853. [CrossRef] [PubMed]

164. Seidemann, K.; Tiemann, M.; Lauterbach, I.; Mann, G.; Simonitsch, I.; Stankewitz, K.; Schrappe, M.; Zimmermann, M.; Niemeyer, C.; Parwaresch, R.; et al. NHL Berlin-Frankfurt-Münster Group Primary mediastinal large B-cell lymphoma with sclerosis in pediatric and adolescent patients: Treatment and results from three therapeutic studies of the Berlin-Frankfurt-Münster Group. J. Clin. Oncol. 2003, 21, 1782-1789. [CrossRef] [PubMed] 
165. Gerrard, M.; Waxman, I.M.; Sposto, R.; Auperin, A.; Perkins, S.L.; Goldman, S.; Harrison, L.; Pinkerton, R.; McCarthy, K.; Raphael, M.; et al. French-American-British/Lymphome Malins de Burkitt 96 (FAB/LMB 96) International Study Committee Outcome and pathologic classification of children and adolescents with mediastinal large B-cell lymphoma treated with FAB/LMB96 mature B-NHL therapy. Blood 2013, 121, 278-285. [CrossRef] [PubMed]

166. Burkhardt, B.; Oschlies, I.; Klapper, W.; Zimmermann, M.; Woessmann, W.; Meinhardt, A.; Landmann, E.; Attarbaschi, A.; Niggli, F.; Schrappe, M.; et al. Non-Hodgkin's lymphoma in adolescents: Experiences in 378 adolescent NHL patients treated according to pediatric NHL-BFM protocols. Leukemia 2011, 25, 153-160. [CrossRef] [PubMed]

167. Cairo, M.S.; Sposto, R.; Gerrard, M.; Auperin, A.; Goldman, S.C.; Harrison, L.; Pinkerton, R.; Raphael, M.; McCarthy, K.; Perkins, S.L.; et al. Advanced stage, increased lactate dehydrogenase, and primary site, but not adolescent age ( $\geq 15$ years), are associated with an increased risk of treatment failure in children and adolescents with mature B-cell non-Hodgkin's lymphoma: Results of the FAB LMB 96 study. J. Clin. Oncol. 2012, 30, 387-393. [CrossRef] [PubMed]

168. Kluiver, J.; Poppema, S.; de Jong, D.; Blokzijl, T.; Harms, G.; Jacobs, S.; Kroesen, B.-J.; van den Berg, A. BIC and miR-155 are highly expressed in Hodgkin, primary mediastinal and diffuse large B cell lymphomas. J. Pathol. 2005, 207, 243-249. [CrossRef] [PubMed]

169. Romero, M.; Gapihan, G.; Castro-Vega, L.J.; Acevedo, A.; Wang, L.; Li, Z.W.; Bouchtaoui, M.E.; Di Benedetto, M.; Ratajczak, P.; Feugeas, J.-P.; et al. Primary mediastinal large B-cell lymphoma: Transcriptional regulation by miR-92a through FOXP1 targeting. Oncotarget 2017, 8, 16243-16258. [CrossRef] [PubMed]

170. Malpeli, G.; Barbi, S.; Tosadori, G.; Greco, C.; Zupo, S.; Pedron, S.; Brunelli, M.; Bertolaso, A.; Scupoli, M.T.; Krampera, M.; et al. MYC-related microRNAs signatures in non-Hodgkin B-cell lymphomas and their relationships with core cellular pathways. Oncotarget 2018, 9, 29753-29771. [CrossRef] [PubMed]

171. Burkhardt, B.; Zimmermann, M.; Oschlies, I.; Niggli, F.; Mann, G.; Parwaresch, R.; Riehm, H.; Schrappe, M.; Reiter, A.; BFM Group. The impact of age and gender on biology, clinical features and treatment outcome of non-Hodgkin lymphoma in childhood and adolescence. Br. J. Haematol. 2005, 131, 39-49. [CrossRef] [PubMed]

172. Morris, S.W.; Kirstein, M.N.; Valentine, M.B.; Dittmer, K.G.; Shapiro, D.N.; Saltman, D.L.; Look, A.T. Fusion of a kinase gene, ALK, to a nucleolar protein gene, NPM, in non-Hodgkin's lymphoma. Science 1994, 263, 1281-1284. [CrossRef] [PubMed]

173. Liu, C.; Iqbal, J.; Teruya-Feldstein, J.; Shen, Y.; Dabrowska, M.J.; Dybkaer, K.; Lim, M.S.; Piva, R.; Barreca, A.; Pellegrino, E.; et al. MicroRNA expression profiling identifies molecular signatures associated with anaplastic large cell lymphoma. Blood 2013, 122, 2083-2092. [CrossRef] [PubMed]

174. Steinhilber, J.; Bonin, M.; Walter, M.; Fend, F.; Bonzheim, I.; Quintanilla-Martinez, L. Next-generation sequencing identifies deregulation of microRNAs involved in both innate and adaptive immune response in $\mathrm{ALK}^{+}$ALCL. PLoS ONE 2015, 10, e0117780. [CrossRef] [PubMed]

175. Dejean, E.; Renalier, M.H.; Foisseau, M.; Agirre, X.; Joseph, N.; de Paiva, G.R.; Al Saati, T.; Soulier, J.; Desjobert, C.; Lamant, L.; et al. Hypoxia-microRNA-16 downregulation induces VEGF expression in anaplastic lymphoma kinase (ALK)-positive anaplastic large-cell lymphomas. Leukemia 2011, 25, 1882-1890. [CrossRef] [PubMed]

176. Merkel, O.; Hamacher, F.; Laimer, D.; Sifft, E.; Trajanoski, Z.; Scheideler, M.; Egger, G.; Hassler, M.R.; Thallinger, C.; Schmatz, A.; et al. Identification of differential and functionally active miRNAs in both anaplastic lymphoma kinase (ALK) ${ }^{+}$and $\mathrm{ALK}^{-}$anaplastic large-cell lymphoma. Proc. Natl. Acad. Sci. USA 2010, 107, 16228-16233. [CrossRef] [PubMed]

177. Spaccarotella, E.; Pellegrino, E.; Ferracin, M.; Ferreri, C.; Cuccuru, G.; Liu, C.; Iqbal, J.; Cantarella, D.; Taulli, R.; Provero, P.; et al. STAT3-mediated activation of microRNA cluster 17 92 promotes proliferation and survival of ALK-positive anaplastic large cell lymphoma. Haematologica 2014, 99, 116-124. [CrossRef] [PubMed]

178. Merkel, O.; Hamacher, F.; Griessl, R.; Grabner, L.; Schiefer, A.-I.; Prutsch, N.; Baer, C.; Egger, G.; Schlederer, M.; Krenn, P.W.; et al. Oncogenic role of miR-155 in anaplastic large cell lymphoma lacking the $\mathrm{t}(2 ; 5)$ translocation. J. Pathol. 2015, 236, 445-456. [CrossRef] [PubMed]

179. Cile Desjobert, C.; Ne Renalier, M.-H.; Bergalet, J.; Dejean, E.; Joseph, N.; Kruczynski, A.; Soulier, J.; Espinos, E.; Meggetto, F.; Rome Cavaillé, J.; et al. MiR-29a down-regulation in ALK-positive anaplastic large 
cell lymphomas contributes to apoptosis blockade through MCL-1 overexpression. Blood 2011. [CrossRef] [PubMed]

180. Vishwamitra, D.; Li, Y.; Wilson, D.; Manshouri, R.; Curry, C.V.; Shi, B.; Tang, X.M.; Sheehan, A.M.; Wistuba, I.I.; Shi, P.; et al. MicroRNA 96 is a post-transcriptional suppressor of anaplastic lymphoma kinase expression. Am. J. Pathol. 2012, 180, 1772-1780. [CrossRef] [PubMed]

181. Hoareau-Aveilla, C.; Valentin, T.; Daugrois, C.; Quelen, C.; Mitou, G.; Quentin, S.; Jia, J.; Spicuglia, S.; Ferrier, P.; Ceccon, M.; et al. Reversal of microRNA-150 silencing disadvantages crizotinib-resistant NPM-ALK(+) cell growth. J. Clin. Investig. 2015, 125, 3505-3518. [CrossRef] [PubMed]

182. Congras, A.; Caillet, N.; Torossian, N.; Quelen, C.; Daugrois, C.; Brousset, P.; Lamant, L.; Meggetto, F.; Hoareau-Aveilla, C. Doxorubicin-induced loss of DNA topoisomerase II and DNMT1- dependent suppression of MiR-125b induces chemoresistance in ALK-positive cells. Oncotarget 2018, 9, 14539-14551. [CrossRef] [PubMed]

183. Cortelazzo, S.; Ferreri, A.; Hoelzer, D.; Ponzoni, M. Lymphoblastic lymphoma. Crit. Rev. Oncol. Hematol. 2017, 113, 304-317. [CrossRef] [PubMed]

184. Shankland, K.R.; Armitage, J.O.; Hancock, B.W. Non-Hodgkin lymphoma. Lancet 2012, 380, $848-857$. [CrossRef]

185. Burkhardt, B. Paediatric lymphoblastic T-cell leukaemia and lymphoma: One or two diseases? Br. J. Haematol. 2009, 149, 653-668. [CrossRef] [PubMed]

186. González-Gugel, E.; Villa-Morales, M.; Santos, J.; Bueno, M.J.; Malumbres, M.; Rodríguez-Pinilla, S.M.; Piris, M.Á.; Fernández-Piqueras, J. Down-regulation of specific miRNAs enhances the expression of the gene Smoothened and contributes to T-cell lymphoblastic lymphoma development. Carcinogenesis 2013, 34, 902-908. [CrossRef] [PubMed]

187. Mussolin, L.; Holmes, A.B.; Romualdi, C.; Sales, G.; D’Amore, E.S.G.; Ghisi, M.; Pillon, M.; Rosolen, A.; Basso, K. An aberrant microRNA signature in childhood T-cell lymphoblastic lymphoma affecting CDKN1B expression, NOTCH1 and growth factor signaling pathways. Leukemia 2014, 28, 1909-1912. [CrossRef] [PubMed]

188. Xi, Y.; Li, J.; Zhang, P.; Bai, W.; Gao, N.; Bai, W.; Zhang, Y.; Wu, Y.; Ning, Y. Upregulation of miRNA-17 and miRNA-19 is associated with unfavorable prognosis in patients with T-cell lymphoblastic lymphoma. Exp. Mol. Pathol. 2015, 99, 297-302. [CrossRef] [PubMed]

189. Fan, F.-Y.; Deng, R.; Yi, H.; Sun, H.-P.; Zeng, Y.; He, G.-C.; Su, Y. The inhibitory effect of MEG3/miR-214/AIFM2 axis on the growth of T-cell lymphoblastic lymphoma. Int. J. Oncol. 2017, 51, 316-326. [CrossRef] [PubMed]

190. Qian, D.; Chen, K.; Deng, H.; Rao, H.; Huang, H.; Liao, Y.; Sun, X.; Lu, S.; Yuan, Z.; Xie, D.; et al. MicroRNA-374b Suppresses Proliferation and Promotes Apoptosis in T-cell Lymphoblastic Lymphoma by Repressing AKT1 and Wnt-16. Clin. Cancer Res. 2015, 21, 4881-4891. [CrossRef] [PubMed]

191. López-Nieva, P.; Fernández-Navarro, P.; Vaquero-Lorenzo, C.; Villa-Morales, M.; Graña-Castro, O.; Cobos-Fernández, M.Á.; López-Lorenzo, J.L.; Llamas, P.; González-Sanchez, L.; Sastre, I.; et al. RNA-Seq reveals the existence of a CDKN1C-E2F1-TP53 axis that is altered in human T-cell lymphoblastic lymphomas. BMC Cancer 2018, 18, 430. [CrossRef] [PubMed]

192. Kelly, K.M. Hodgkin lymphoma in children and adolescents: Improving the therapeutic index. Blood 2015, 126, 2452-2458. [CrossRef] [PubMed]

193. Meti, N.; Esfahani, K.; Johnson, N. The Role of Immune Checkpoint Inhibitors in Classical Hodgkin Lymphoma. Cancers 2018, 10, 204. [CrossRef] [PubMed]

194. Bair, S.M.; Mato, A.; Svoboda, J. Immunotherapy for the Treatment of Hodgkin Lymphoma: An Evolving Paradigm. Clin. Lymphoma Myeloma Leuk. 2018, 18, 380-391. [CrossRef] [PubMed]

195. Sherief, L.M.; Elsafy, U.R.; Abdelkhalek, E.R.; Kamal, N.M.; Elbehedy, R.; Hassan, T.H.; Sherbiny, H.S.; Beshir, M.R.; Saleh, S.H. Hodgkin lymphoma in childhood: Clinicopathological features and therapy outcome at 2 centers from a developing country. Medicine 2015, 94, e670. [CrossRef] [PubMed]

196. Navarro, A.; Diaz, T.; Martinez, A.; Gaya, A.; Pons, A.; Gel, B.; Codony, C.; Ferrer, G.; Martinez, C.; Montserrat, E.; et al. Regulation of JAK2 by miR-135a: Prognostic impact in classic Hodgkin lymphoma. Blood 2009, 114, 2945-2951. [CrossRef] [PubMed]

197. Navarro, A.; Gaya, A.; Martinez, A.; Urbano-Ispizua, A.; Pons, A.; Balague, O.; Gel, B.; Abrisqueta, P.; Lopez-Guillermo, A.; Artells, R.; et al. MicroRNA expression profiling in classic Hodgkin lymphoma. Blood 2008, 111, 2825-2832. [CrossRef] [PubMed] 
198. Huang, X.; Zhou, X.; Wang, Z.; Li, F.; Liu, F.; Zhong, L.; Li, X.; Han, X.; Wu, Z.; Chen, S.; et al. CD99 triggers upregulation of miR-9-modulated PRDM1/BLIMP1 in Hodgkin/Reed-Sternberg cells and induces redifferentiation. Int. J. Cancer 2012, 131, E382-E394. [CrossRef] [PubMed]

199. Khare, D.; Goldschmidt, N.; Bardugo, A.; Gur-Wahnon, D.; Ben-Dov, I.Z.; Avni, B. Plasma microRNA profiling: Exploring better biomarkers for lymphoma surveillance. PLoS ONE 2017, 12, e0187722. [CrossRef] [PubMed]

200. Paydas, S.; Acikalin, A.; Ergin, M.; Celik, H.; Yavuz, B.; Tanriverdi, K. Micro-RNA (miRNA) profile in Hodgkin lymphoma: Association between clinical and pathological variables. Med. Oncol. 2016, 33, 34. [CrossRef] [PubMed]

201. Gibcus, J.H.; Kroesen, B.-J.; Koster, R.; Halsema, N.; de Jong, D.; de Jong, S.; Poppema, S.; Kluiver, J.; Diepstra, A.; van den Berg, A. MiR-17/106b seed family regulates p21 in Hodgkin's lymphoma. J. Pathol. 2011, 225, 609-617. [CrossRef] [PubMed]

202. Zhu, M.; Xu, Z.; Wang, K.; Wang, N.; Zhu, M.; Wang, S. MicroRNA and gene networks in human Hodgkin's lymphoma. Mol. Med. Rep. 2013, 8, 1747-1754. [CrossRef] [PubMed]

203. Yuan, Y.; Kluiver, J.; Koerts, J.; de Jong, D.; Rutgers, B.; Abdul Razak, F.R.; Terpstra, M.; Plaat, B.E.; Nolte, I.M.; Diepstra, A.; et al. miR-24-3p Is Overexpressed in Hodgkin Lymphoma and Protects Hodgkin and Reed-Sternberg Cells from Apoptosis. Am. J. Pathol. 2017, 187, 1343-1355. [CrossRef] [PubMed]

204. Leucci, E.; Zriwil, A.; Gregersen, L.H.; Jensen, K.T.; Obad, S.; Bellan, C.; Leoncini, L.; Kauppinen, S.; Lund, A.H. Inhibition of miR-9 de-represses HuR and DICER1 and impairs Hodgkin lymphoma tumour outgrowth in vivo. Oncogene 2012, 31, 5081-5089. [CrossRef] [PubMed]

205. Van Vlierberghe, P.; De Weer, A.; Mestdagh, P.; Feys, T.; De Preter, K.; De Paepe, P.; Lambein, K.; Vandesompele, J.; Van Roy, N.; Verhasselt, B.; et al. Comparison of miRNA profiles of microdissected Hodgkin/Reed-Sternberg cells and Hodgkin cell lines versus CD77 ${ }^{+}$B-cells reveals a distinct subset of differentially expressed miRNAs. Br. J. Haematol. 2009, 147, 686-690. [CrossRef] [PubMed]

206. Gibcus, J.H.; Tan, L.P.; Harms, G.; Schakel, R.N.; de Jong, D.; Blokzijl, T.; Möller, P.; Poppema, S.; Kroesen, B.-J.; van den Berg, A. Hodgkin lymphoma cell lines are characterized by a specific miRNA expression profile. Neoplasia 2009, 11, 167-176. [CrossRef] [PubMed]

207. Lawrie, C.H.; Gal, S.; Dunlop, H.M.; Pushkaran, B.; Liggins, A.P.; Pulford, K.; Banham, A.H.; Pezzella, F.; Boultwood, J.; Wainscoat, J.S.; et al. Detection of elevated levels of tumour-associated microRNAs in serum of patients with diffuse large B-cell lymphoma. Br. J. Haematol. 2008, 141, 672-675. [CrossRef] [PubMed]

208. Pezuk, J.A. The Importance of Circulating miRNAs and Its Limitation on the Clinic. Hum. J. Rev. Artic. Novemb. Ijsrm. Hum. 2017, 8, 278-283.

209. Stamatopoulos, B.; Van Damme, M.; Crompot, E.; Dessars, B.; El Housni, H.; Mineur, P.; Meuleman, N.; Bron, D.; Lagneaux, L. Opposite Prognostic Significance of Cellular and Serum Circulating MicroRNA-150 in Patients with Chronic Lymphocytic Leukemia. Mol. Med. 2015, 21, 123-133. [CrossRef] [PubMed]

210. Jones, K.; Nourse, J.P.; Keane, C.; Bhatnagar, A.; Gandhi, M.K. Plasma MicroRNA Are Disease Response Biomarkers in Classical Hodgkin Lymphoma. Clin. Cancer Res. 2014, 20, 253-264. [CrossRef] [PubMed]

211. Swellam, M.; El-Khazragy, N. Clinical impact of circulating microRNAs as blood-based marker in childhood acute lymphoblastic leukemia. Tumor Biol. 2016, 37, 10571-10576. [CrossRef] [PubMed]

212. Swellam, M.; Hashim, M.; Mahmoud, M.S.; Ramadan, A.; Hassan, N.M. Aberrant Expression of Some Circulating miRNAs in Childhood Acute Lymphoblastic Leukemia. Biochem. Genet. 2018, 56, $283-294$. [CrossRef] [PubMed]

213. Fayyad-Kazan, H.; Bitar, N.; Najar, M.; Lewalle, P.; Fayyad-Kazan, M.; Badran, R.; Hamade, E.; Daher, A.; Hussein, N.; ElDirani, R.; et al. Circulating miR-150 and miR-342 in plasma are novel potential biomarkers for acute myeloid leukemia. J. Transl. Med. 2013, 11, 31. [CrossRef] [PubMed]

214. Lin, X.; Wang, Z.; Zhang, R.; Feng, W. High serum microRNA-335 level predicts aggressive tumor progression and unfavorable prognosis in pediatric acute myeloid leukemia. Clin. Transl. Oncol. 2015, 17, 358-364. [CrossRef] [PubMed]

215. Guo, H.-Q.; Huang, G.-L.; Guo, C.-C.; Pu, X.-X.; Lin, T.-Y. Diagnostic and prognostic value of circulating miR-221 for extranodal natural killer/T-cell lymphoma. Dis. Mark. 2010, 29, 251-258. [CrossRef]

216. Zhao, Q.; Li, J.; Chen, S.; Shen, K.; Ai, G.; Dai, X.; Xie, B.; Shi, Y.; Jiang, S.; Feng, J.; et al. Decreased miR-144 expression as a non-invasive biomarker for acute myeloid leukemia patients. Pharmazie 2017, 72, $232-235$. [CrossRef] [PubMed] 
217. Huang, Y.; Zou, Y.; Lin, L.; Ma, X.; Chen, H. Identification of serum miR-34a as a potential biomarker in acute myeloid leukemia. Cancer Biomark. 2018, 22, 799-855. [CrossRef] [PubMed]

218. Lin, X.; Wang, Z.; Wang, Y.; Feng, W. Serum MicroRNA-370 as a potential diagnostic and prognostic biomarker for pediatric acute myeloid leukemia. Int. J. Clin. Exp. Pathol. 2015, 8, 14658-14666. [PubMed]

219. Hong, Z.; Zhang, R.; Qi, H. Diagnostic and prognostic relevance of serum miR-195 in pediatric acute myeloid leukemia. Cancer Biomark. 2018, 21, 269-275. [CrossRef] [PubMed]

220. Chen, W.; Wang, H.; Chen, H.; Liu, S.; Lu, H.; Kong, D.; Huang, X.; Kong, Q.; Lu, Z. Clinical significance and detection of microRNA-21 in serum of patients with diffuse large B-cell lymphoma in Chinese population. Eur. J. Haematol. 2014, 92, 407-412. [CrossRef] [PubMed]

221. Lopez-Santillan, M.; Larrabeiti-Etxebarria, A.; Arzuaga-Mendez, J.; Lopez-Lopez, E.; Garcia-Orad, A. Circulating miRNAs as biomarkers in diffuse large B-cell lymphoma: A systematic review. Oncotarget 2018, 9, 22850-22861. [CrossRef] [PubMed]

222. Ahmadvand, M.; Eskandari, M.; Pashaiefar, H.; Yaghmaie, M.; Manoochehrabadi, S.; Khakpour, G.; Sheikhsaran, F.; Montazer Zohour, M. Over expression of circulating miR-155 predicts prognosis in diffuse large B-cell lymphoma. Leuk. Res. 2018, 70, 45-48. [CrossRef] [PubMed]

223. Marchesi, F.; Regazzo, G.; Palombi, F.; Terrenato, I.; Sacconi, A.; Spagnuolo, M.; Donzelli, S.; Marino, M.; Ercolani, C.; Di Benedetto, A.; et al. Serum miR-22 as potential non-invasive predictor of poor clinical outcome in newly diagnosed, uniformly treated patients with diffuse large B-cell lymphoma: An explorative pilot study. J. Exp. Clin. Cancer Res. 2018, 37, 95. [CrossRef] [PubMed]

224. Yuan, W.X.; Gui, Y.X.; Na, W.N.; Chao, J.; Yang, X. Circulating microRNA-125b and microRNA-130a expression profiles predict chemoresistance to R-CHOP in diffuse large B-cell lymphoma patients. Oncol. Lett. 2016, 11, 423-432. [CrossRef] [PubMed]

225. Beta, M.; Krishnakumar, S.; Elchuri, S.V.; Salim, B.; Narayanan, J. A comparative fluorescent beacon-based method for serum microRNA quantification. Anal. Sci. 2015, 31, 231-235. [CrossRef] [PubMed]

226. Li, J.; Zhai, X.-W.; Wang, H.-S.; Qian, X.-W.; Miao, H.; Zhu, X.-H. Circulating MicroRNA-21, MicroRNA-23a, and MicroRNA-125b as Biomarkers for Diagnosis and Prognosis of Burkitt Lymphoma in Children. Med. Sci. Monit. 2016, 22, 4992-5002. [CrossRef] [PubMed]

227. Babar, I.A.; Cheng, C.J.; Booth, C.J.; Liang, X.; Weidhaas, J.B.; Saltzman, W.M.; Slack, F.J. Nanoparticle-based therapy in an in vivo microRNA-155 (miR-155)-dependent mouse model of lymphoma. Proc. Natl. Acad. Sci. USA 2012, 109, E1695-E1704. [CrossRef] [PubMed]

228. Tivnan, A.; Orr, W.S.; Gubala, V.; Nooney, R.; Williams, D.E.; McDonagh, C.; Prenter, S.; Harvey, H.; Domingo-Fernández, R.; Bray, I.M.; et al. Inhibition of neuroblastoma tumor growth by targeted delivery of microRNA-34a using anti-disialoganglioside GD2 coated nanoparticles. PLoS ONE 2012, 7, e38129. [CrossRef] [PubMed]

229. Hsu, S.-H.; Yu, B.; Wang, X.; Lu, Y.; Schmidt, C.R.; Lee, R.J.; Lee, L.J.; Jacob, S.T.; Ghoshal, K. Cationic lipid nanoparticles for therapeutic delivery of siRNA and miRNA to murine liver tumor. Nanomedicine 2013, 9 , 1169-1180. [CrossRef] [PubMed]

230. Gill, S.-L.; O’Neill, H.; McCoy, R.J.; Logeswaran, S.; O’Brien, F.; Stanton, A.; Kelly, H.; Duffy, G.P. Enhanced delivery of microRNA mimics to cardiomyocytes using ultrasound responsive microbubbles reverses hypertrophy in an in-vitro model. Technol. Health Care 2014, 22, 37-51. [CrossRef] [PubMed]

231. Liu, J.; Dang, L.; Li, D.; Liang, C.; He, X.; Wu, H.; Qian, A.; Yang, Z.; Au, D.W.T.; Chiang, M.W.L.; et al. A delivery system specifically approaching bone resorption surfaces to facilitate therapeutic modulation of microRNAs in osteoclasts. Biomaterials 2015, 52, 148-160. [CrossRef] [PubMed]

232. Wang, S.; Cao, M.; Deng, X.; Xiao, X.; Yin, Z.; Hu, Q.; Zhou, Z.; Zhang, F.; Zhang, R.; Wu, Y.; et al. Degradable hyaluronic acid/protamine sulfate interpolyelectrolyte complexes as miRNA-delivery nanocapsules for triple-negative breast cancer therapy. Adv. Healthc. Mater. 2015, 4, 281-290. [CrossRef] [PubMed]

233. Janssen, H.L.A.; Reesink, H.W.; Lawitz, E.J.; Zeuzem, S.; Rodriguez-Torres, M.; Patel, K.; van der Meer, A.J.; Patick, A.K.; Chen, A.; Zhou, Y.; et al. Treatment of HCV infection by targeting microRNA. N. Engl. J. Med. 2013, 368, 1685-1694. [CrossRef] [PubMed]

234. Simonson, B.; Das, S. MicroRNA Therapeutics: The Next Magic Bullet? Mini Rev. Med. Chem. 2015, 15, 467-474. [CrossRef] [PubMed] 
235. Cai, C.-K.; Zhao, G.-Y.; Tian, L.-Y.; Liu, L.; Yan, K.; Ma, Y.-L.; Ji, Z.-W.; Li, X.-X.; Han, K.; Gao, J.; et al. miR-15a and miR-16-1 downregulate CCND1 and induce apoptosis and cell cycle arrest in osteosarcoma. Oncol. Rep. 2012, 28, 1764-1770. [CrossRef] [PubMed]

236. Beg, M.S.; Brenner, A.J.; Sachdev, J.; Borad, M.; Kang, Y.-K.; Stoudemire, J.; Smith, S.; Bader, A.G.; Kim, S.; Hong, D.S. Phase I study of MRX34, a liposomal miR-34a mimic, administered twice weekly in patients with advanced solid tumors. Investig. New Drugs 2017, 35, 180-188. [CrossRef] [PubMed] 